العــــــــد السـابع والثلاثون

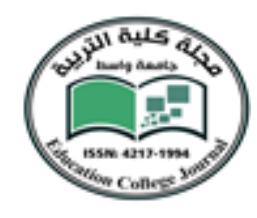

الجزء الثالث/ تشرين الثاني / 19

\title{
الطوفان في المصادر الإيرانية القديمة
}

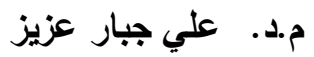 \\ وزلارة التربية / مديرية تربية محافظة واسط علئ عزيز}

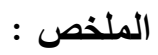

لقد عاش الإنسان منذ القدم في إيران القديمة في صراع مستمر مع البيئة الطبيعة، إذ كان الهذف

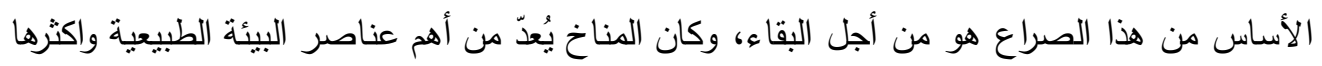

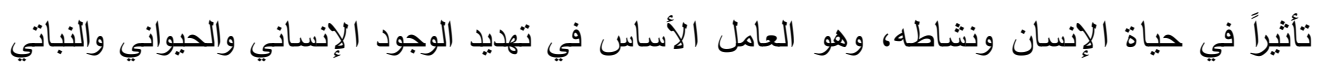

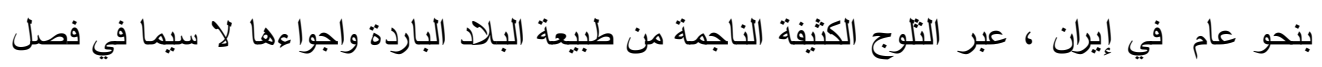

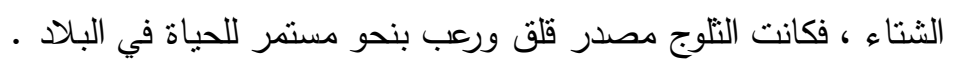

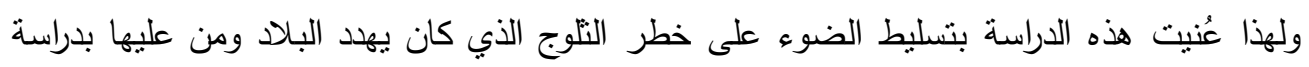

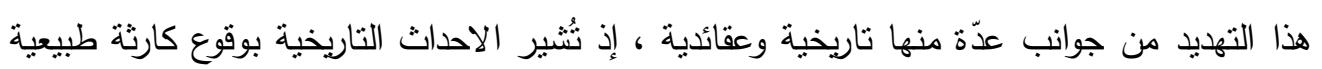

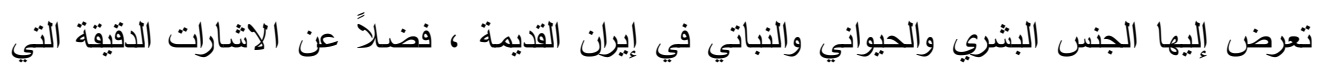

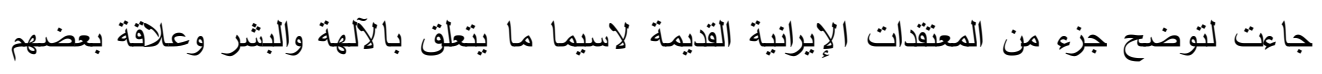

\section{The Flood in Ancient Iranian Sources}

\section{Abstract}

Since ancient times, man has lived in constant conflict with the natural environment. The main objective of this struggle was to survive. The climate, one of the most important elements of the natural environment and the most influential in human life and activity, is the main factor in the threat of human, animal and plant existence. General in Iran, through the dense snow caused by the nature and cold country atmosphere especially in the winter , This study was designed to shed light on this threat, which threatened the country and its people, by examining this threat in many aspects, including historical and ideological in ancient Iran, as historical events indicate the occurrence of a natural disaster Exposed to the human race, animal and plant in ancient Iran, as well as the subtle signs that have come to illustrate some of Iran's ancient beliefs, especially concerning gods and humans and their relationship with each other. 
العــــــــد السـابع والثلاثون

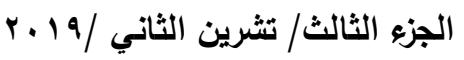

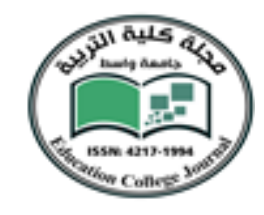

جامعة واسط

مجلـــــة كليـــــة التربيـــــة

المُقَّمة :

يُعدّ الطوفان في إيران القديمة واحداً من العوامل التي ثُشكل تهديداً حقيقياً للوجود الإنساني والحيواني والنباني على حد سواء، لهذا عاش الإنسان في إيران في صراع مستمر مع البيئة الطبيعية من ضمان بقاءه على قبد الحياة.

ولهذا عُنيت هذه الدراسة بتسليط الضوء على خطر التلوج الذي كان يهدد البلاد ومن عليها، بدراسة هذا التهديد من جوانب عدّة منها تاريخية وعقائدية في إيران القديمة ، فضلاً عن الاشارات

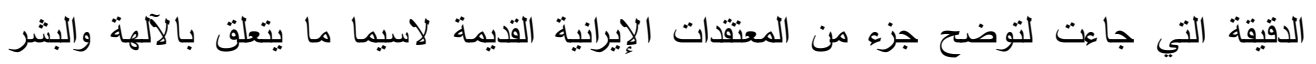

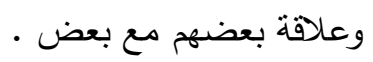

ونحاول في هذه الدراسة توضيح أكثر من فرضية، الأولى: هل أن اسباب حدوث الطوفان

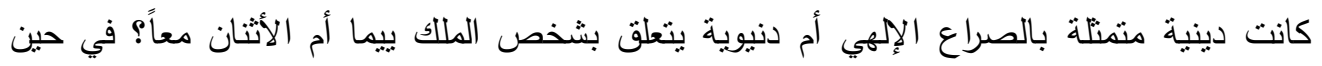

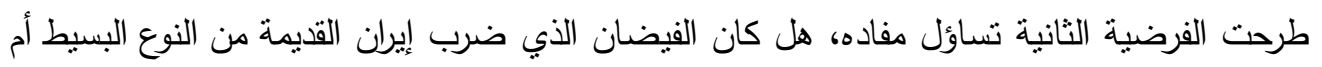

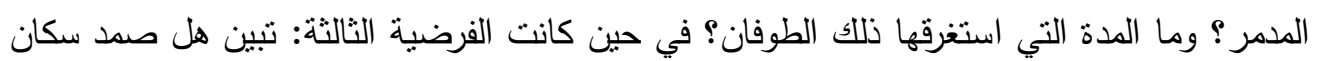

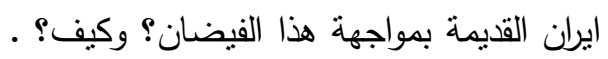

أما عن المنهجية المنبعة في هذه الدراسة (الطوفان في المصادر الإيرانية القليمة)، فكانت

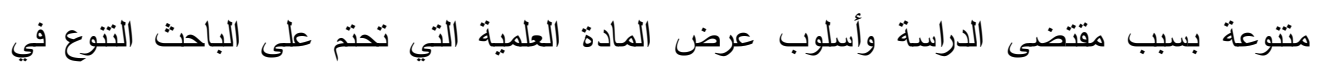

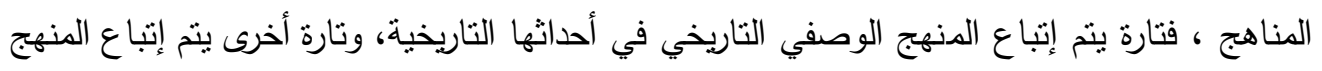

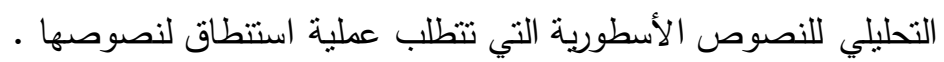
أما عن الدراسات السابقة، فهنا لابد من الإشارة كون هذه الدراسة هي الأولى في هذا

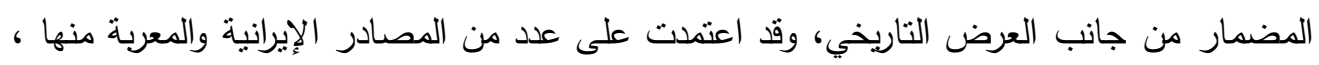
من أهمها كتاب أفستا الذي يُعدّ الكتاب المقدس اللايانة الزرادشتية.

وتضمن الحديث عن (الطوفان في المصادر الإيرانية القيمة) في هذه الدراسة، الإشارة إلى

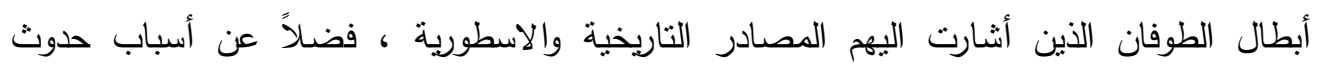

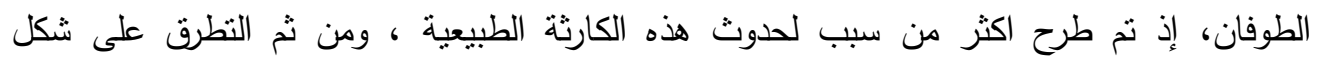

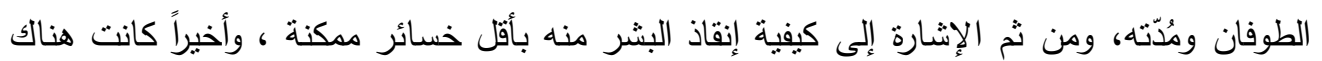




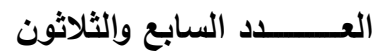

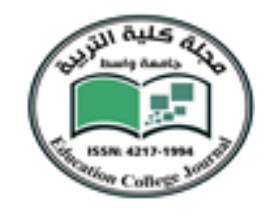

الجزء الثالث/ تشرين الثاني / 19

جامعة واسط

مجلـــــة كليـــــة التربيـــــة

عدد من الاستتتاجات وقفت عندها هذه الدراسة. ونأمل أن نكون قد وفقنا في دراستتا هذه وما لتوفيق

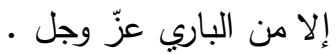

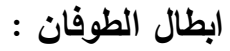

تروي قصة الطوفان الإيرانية القديمة حادثة الطوفان التي كان ابطالها على مستوبين

الأول: الإلهي والمتمنل بالإله (آهوراميزدا Ahura mazda ) وهو الإله الكامل الحكمة، القدوس الأزلي الذي يعلم كل شيء وخالق كل شيء(')، وهو إله النور في الديانة الزرادشتية ، ويُعدّ الإله الأوحد في فعل الخير في اعنقادهم ، فضلاً عن نمتعه بالعديد من الصفات الإيجابية منها التقوى والحق والعقل والطيبة والايمان والخلود... الخ(؟)، في حين كان البطل الثاني : هو أقل درجة من بن

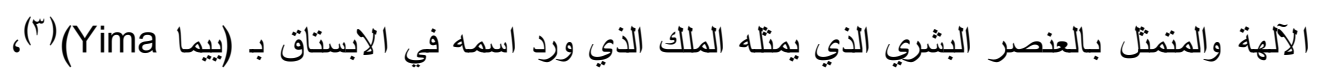
وقد ورد بصيغة اخرى باسم ( جمشيد camšid) الذي هو كلمة مختصة من ( يما خشيتا ) وتعني ( ييما الملك ) وكلمة ( شيد ) تعني الثمس، وإنَّما سُّي بهذا الاسم، لأنّه كان موصوفاً بالجمال الفائق وحسن الخلق (๕)، وقد عرف عن هذا الملك أنّه كان مُحسناً لشعبه ناشراً للعدل والرحمة والإحسان بينهم، وفضلاً عما كان يتمتع به من فطنة وذكاء وتفنن في صناعة آلات الحرب من السيوف والرماح والدروع ... الخ ، إلى جانب استغله المنسوجات الكتانية والأصواف والحرير في صناعة الملابس بعد أن يتم غزلها ونسجها ، وقد انتشرت الصناعات في عهدة حتى عمت أقطار الأرض

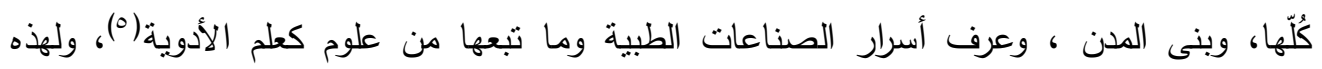
الشهرة اكتسب على إثرها طابعاً أسطورياً، فقد وصفته النصوص الأسطورية الإيرانية على أنه أبن إله اله الشمس( فيفاهفانت Vivanghen)(")، ويُعدّ الملك الأسطوري الثالث من سلهة (برادات Bradat) من البشداديين التي تُمنل السلالمة الرسمية الأولى من بعد الملوك هاوشيانهي وتاهماـوربا وقد حكم

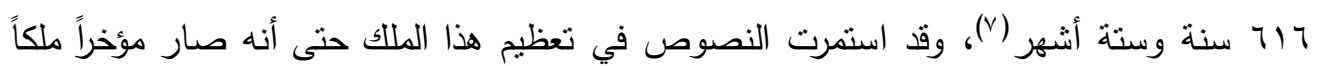
للعالم الآخر ، إذ أنه أختص بالأموات الصالحين فقط (^). 
العــــــــد السـابع والثلاثون

الجزء الثالث/ تشرين الثاني / 19

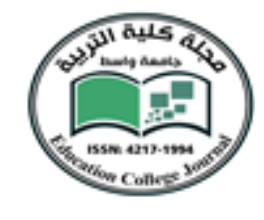

جامعة واسط

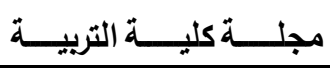

اسباب الطوفان :

ثُشير الدصادر الأسطورية الإيرانية إلى الأسباب الحقيقة التي أسهمت في وقوع الطوفان، بل هناك

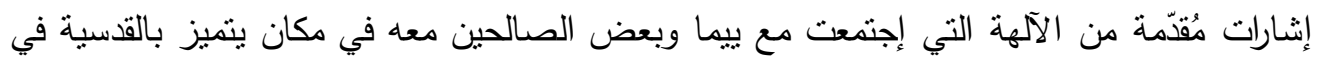

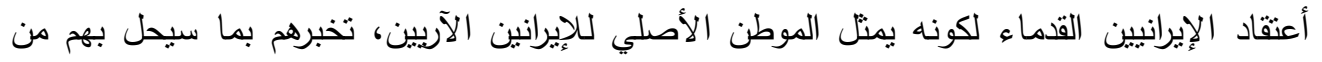
أخطار منلما أشار إلى نلك في النص بقوله :

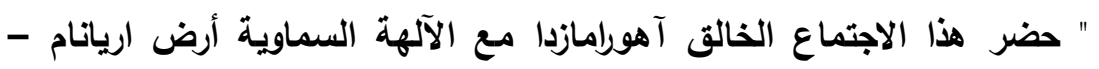

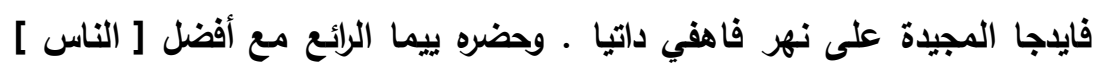

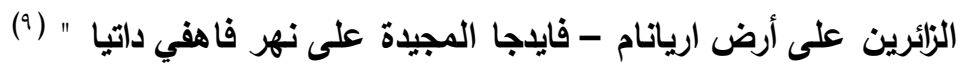

ولكن عند قراءة النصوص وتمحيصها بنحو مفصل مع ربط الأحداث بعضها ببعض؛ نستنتج أن

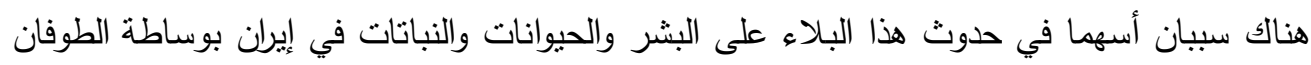

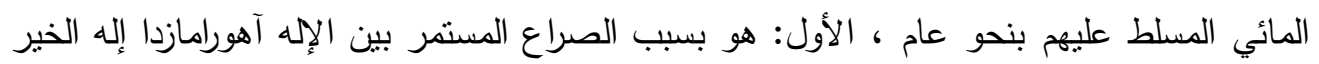

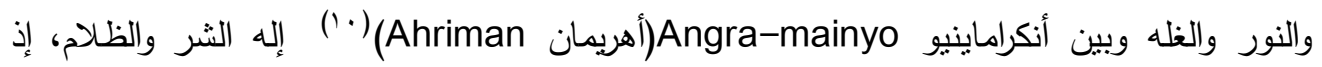

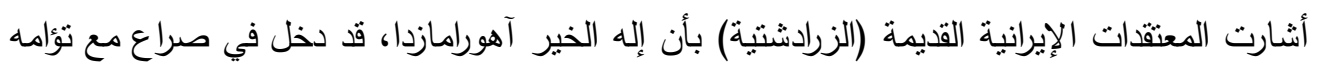

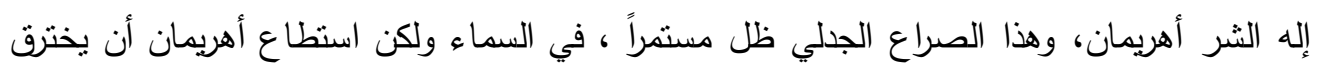

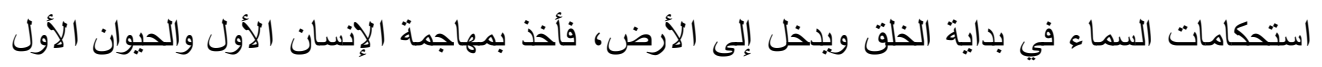

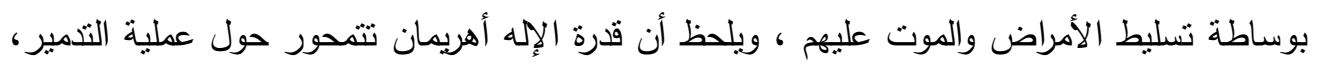

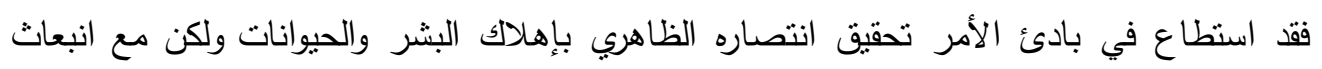

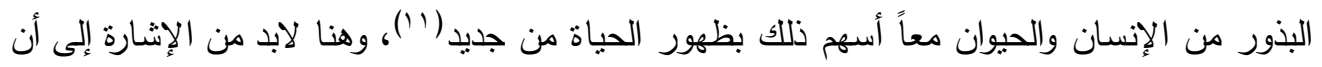

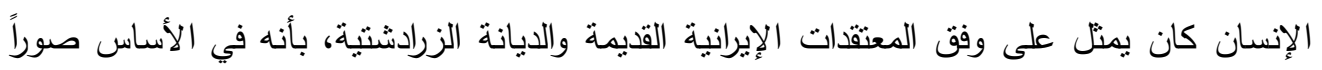

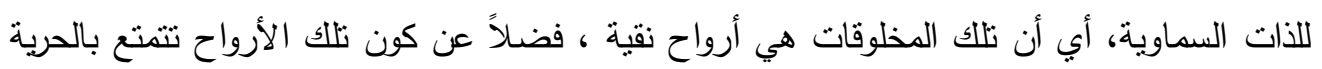

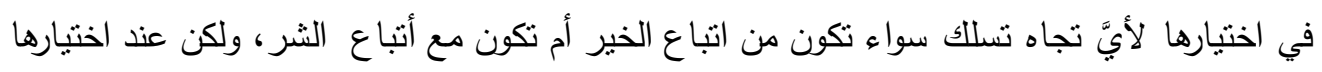

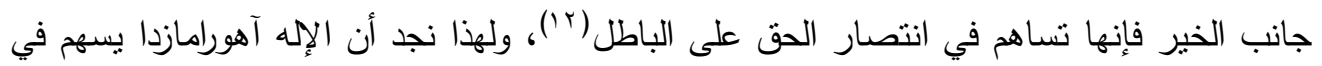

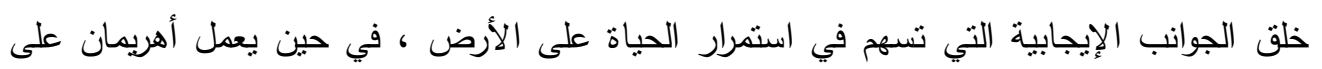

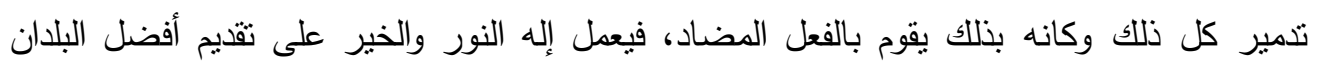

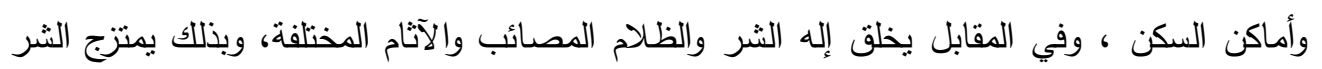


العــــــــد السابع والثثلاثون

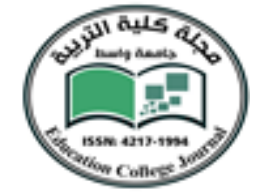

جامعة واسط

الجزء الثالث/ تشرين الثاني / 19

مجلـــــة كليـــــة التربيـــــة

مع كل خلق آهوري، ولهذا نلحظ أن مع كل بلد يخلق يكون سوطه، ومأساته وعذابه وعقابه قد خلق

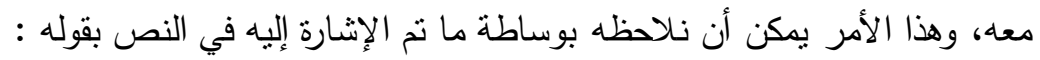

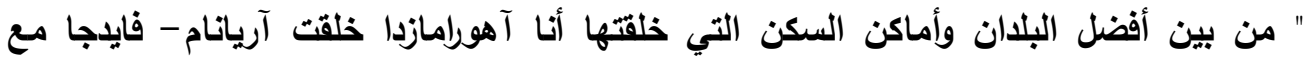

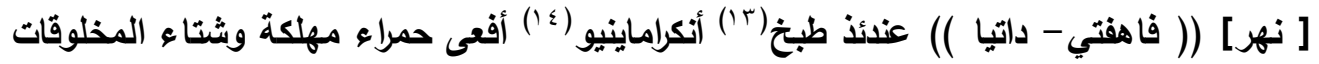

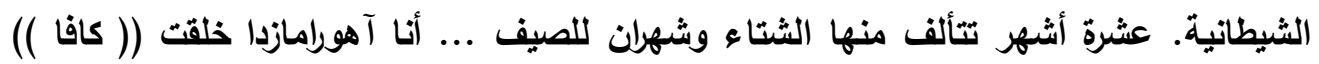

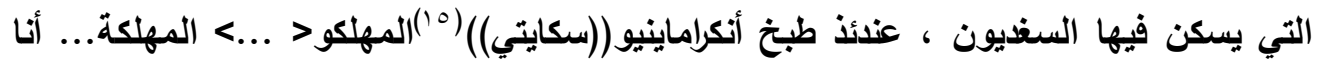

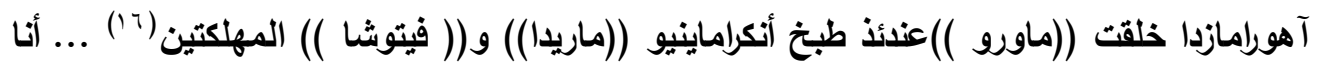

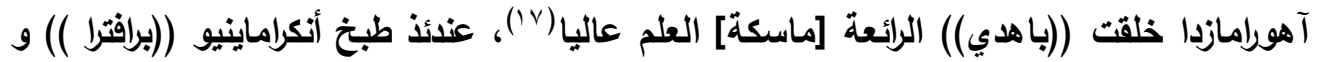

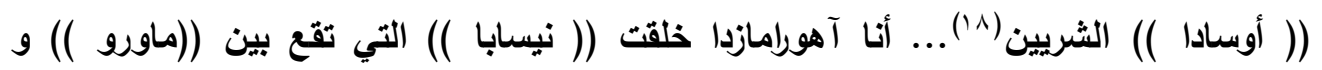

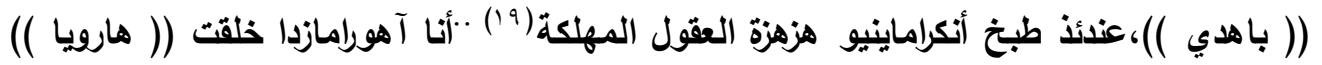

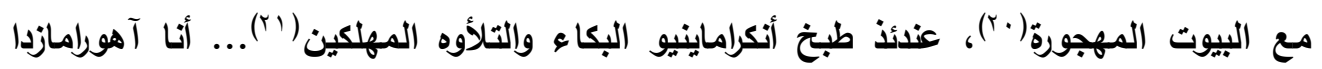

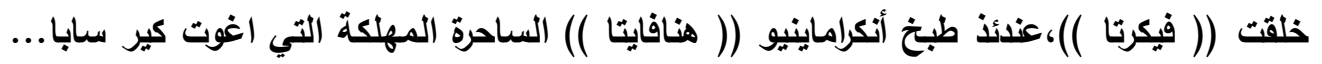

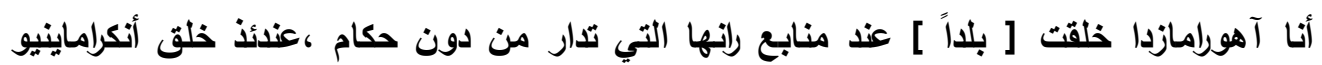

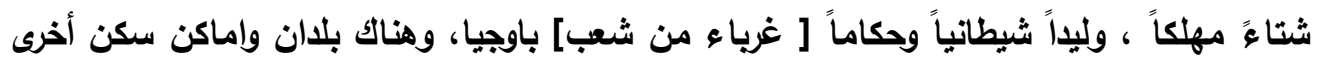

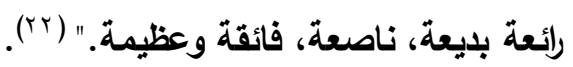

أما السبب الثاني الذي أسهم في حدوث الطوفان فهو الإنسان ، وتحديداً متصنل بالملك ييما

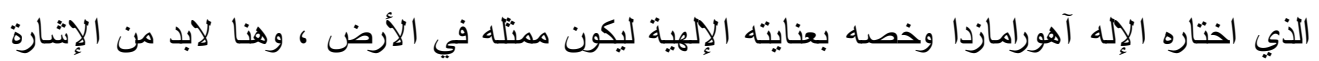

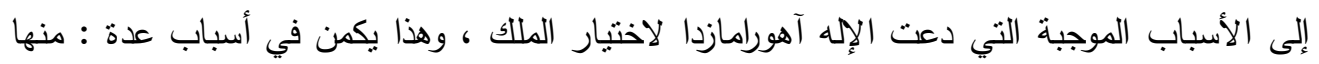
ما يمنلكه من مؤهلات جعلته في مكانة مميزة بين البشر الآخرين كونه من العباد الزهاد الملتزمين

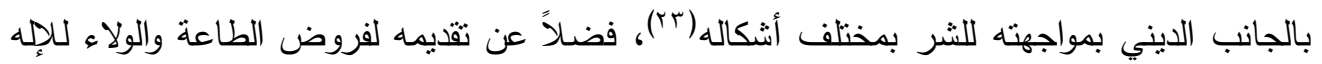

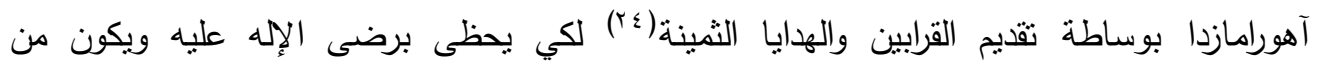

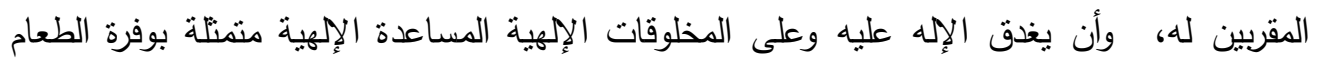

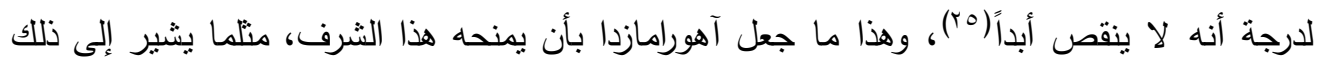

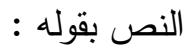


العــــــــد السابع والثثلاثون

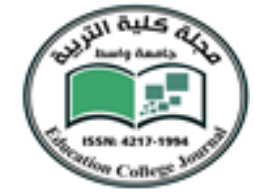

جامعة واسط

الجزء الثالث/ تثرين الثاني / 19

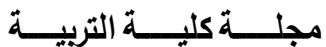

" قدم لله الراعي الصالح ييما قرياناً على أعالي جبل هكاري اللامع، على عرش ذهبي تحت أثعةٍ

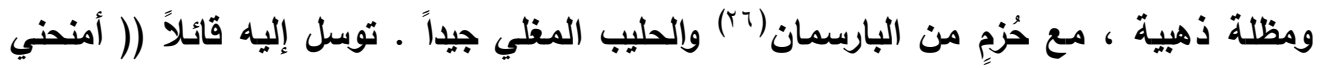

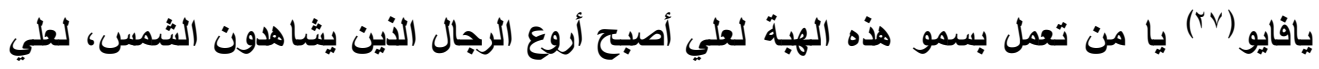

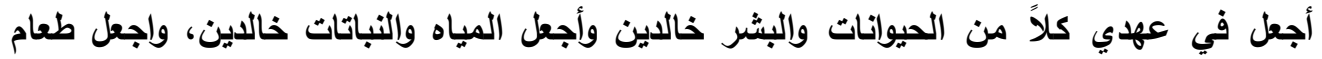

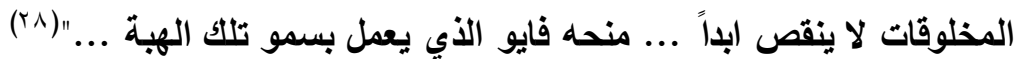

ويبدو أن عملية اختيار آهورامازدا لمنلك في الأرض بيما كان بطريقين: الأول تمثل

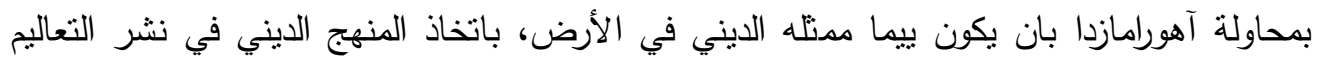

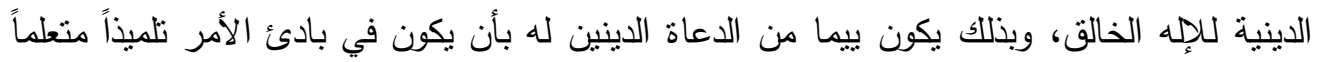

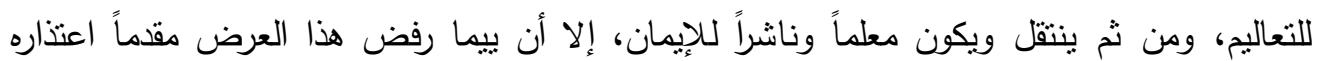
للإلهه متحججاً بكونه من البشر ذوي القدرات المحدودة، وهذا ما وضحه حديث الإن الإله آهورامازدا لزرادشت بما نصه:

"هكذا قلت له أنا آهوامازدا: كنْ لي يا ييما الرائع أبن فيفاهفانت تلميذاً ومعلماً

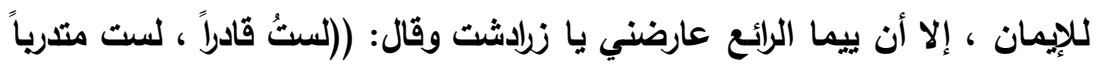

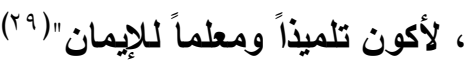

وبعد هذا الرفض أنجه الإله آهورامازدا لسلك الطريق الثاني: بمحاولة اقناع بيما؛ لأن يكون

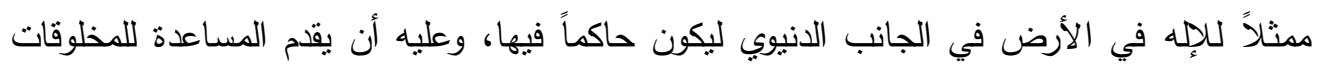

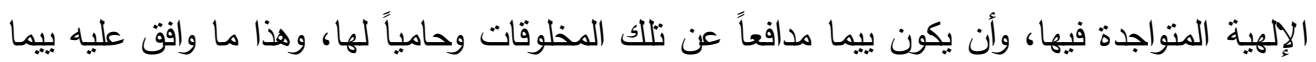

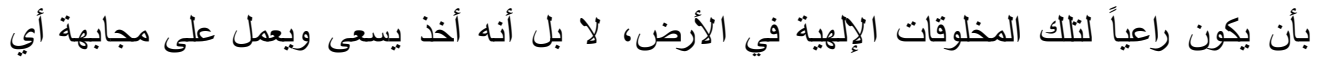

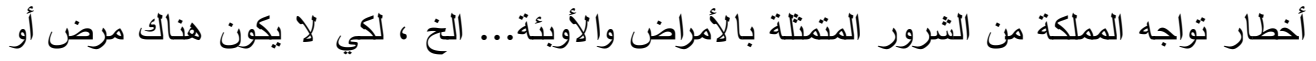
موت ، وقد وضح النص ذللك بقوله :

" عندئذ قُلت له أنا آهورامازدا يا زرادشت : (إذا لم تستطع يا ييما الرائع أن تكون لي تلميذاً ومعلماً

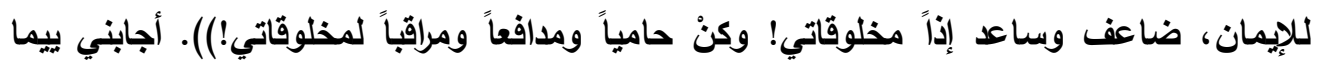

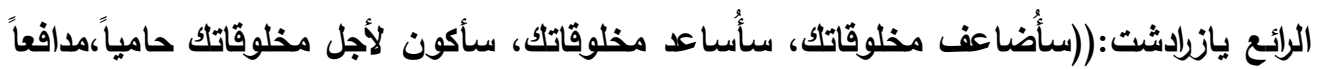

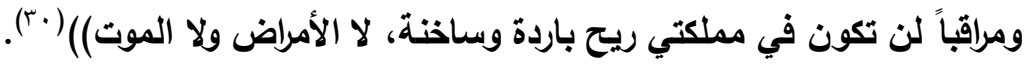


العـــــــــد السـابع والثلاثون

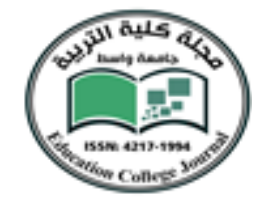

الجزء الثالث/ تشرين الثاني / 19

ولكن هذا الملك الصالح أخذه الغرور والطغيان والتكبر إلى جانب تخليه عن المعونة الالهية

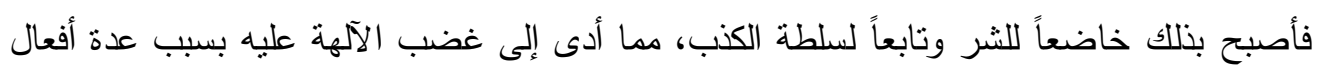
كان قد ارتكبها؛ وهي تمثل خطايا تكون من الصعب غفرانها، ومنها الخطيئة الأولى التي تتمثل باتهام

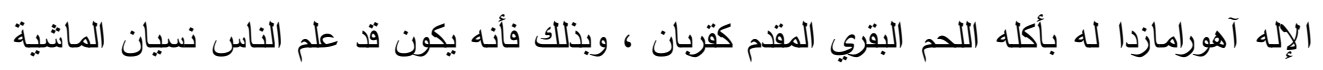

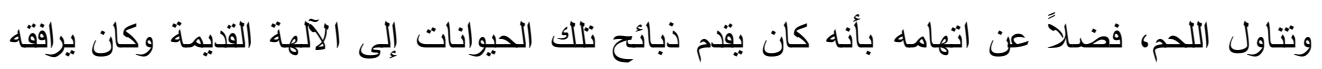

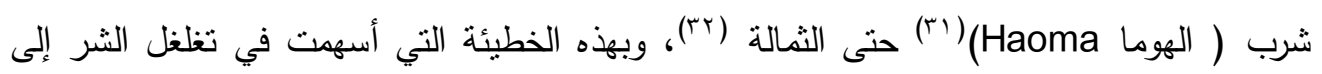
العالم، كما يرد ذلك في النص بقوله :

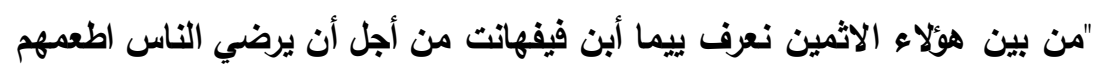

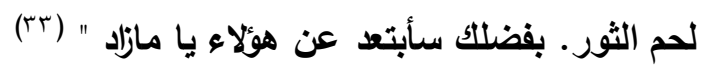

ويتضح من النص المنقم آنفاً ، أن ييما قد أثنار حفيظة الإله آهورامازدا بوساطة خطيئته

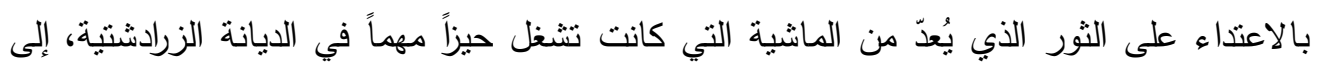

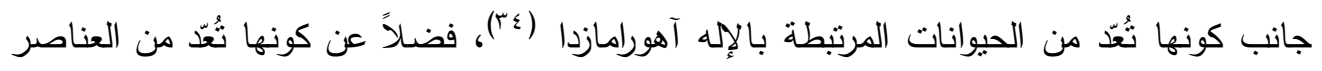

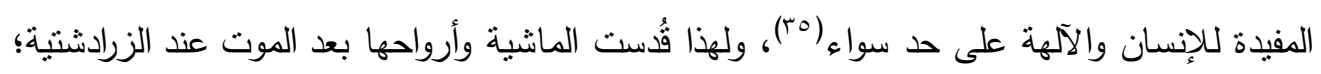

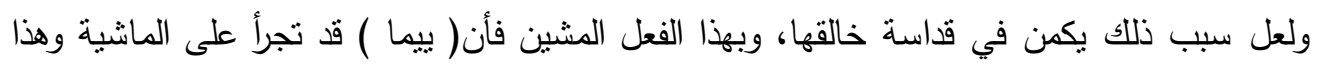

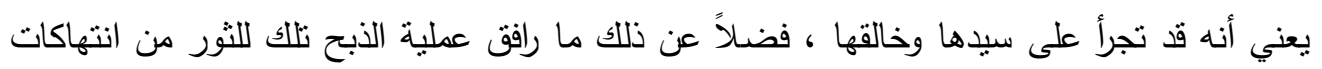

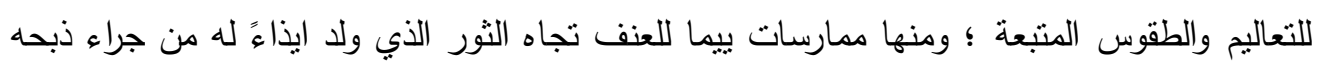

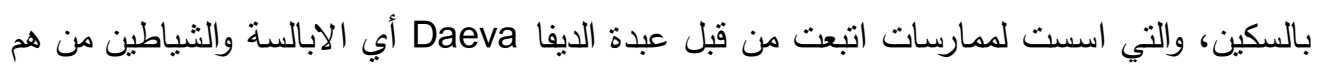

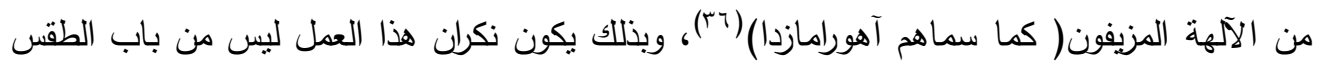

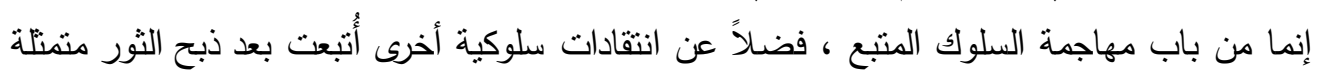

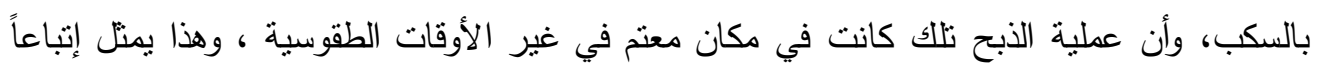

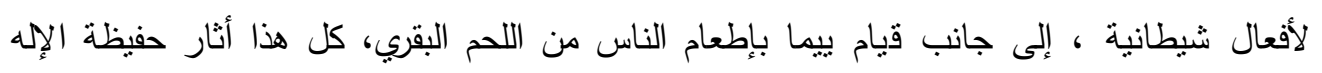

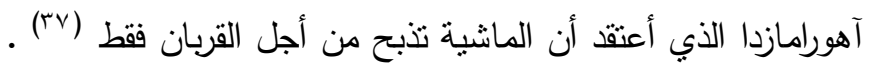
بما أنك ترتكب الذنوب والاخطاء والآثام؛ فهذا بعني أنك تقف بجانب الثر والظلم والظلام ، وبذلك

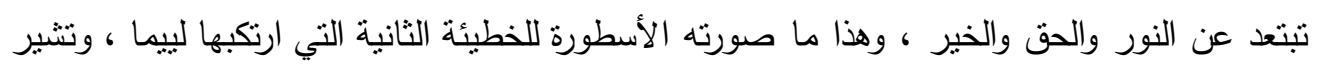

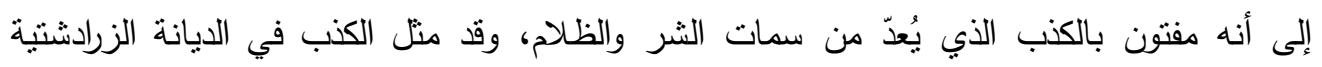

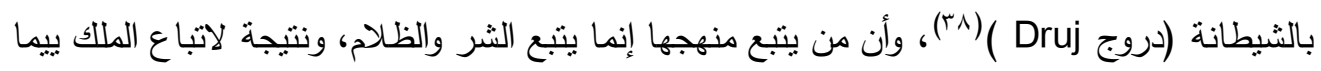


العـــــــــد السـابع والثلاثون

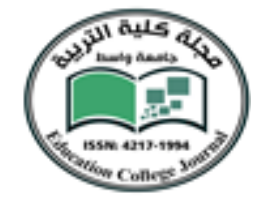

الجزء الثالث/ تشرين الثاني / 19

جامعة واسط

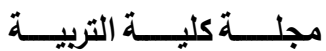

هذا النهج ووقوفه بجانب دروج ، فهذا يعني أنه وقف إلى جانب الشر ضد الخير، ولذلك الموقف كان

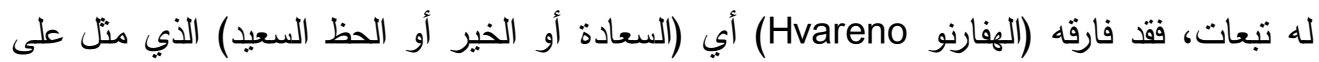

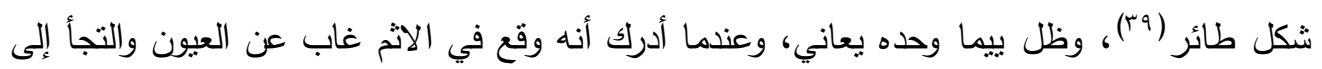
باطن الأرض في العالم الأسفل كما عبرت الأسطورة بقولها:

"عذما كان ييما صادقاً لم يكن في مملكته لا البرد والحر، لا الكنب، لا العواطف ولا الموت ولا

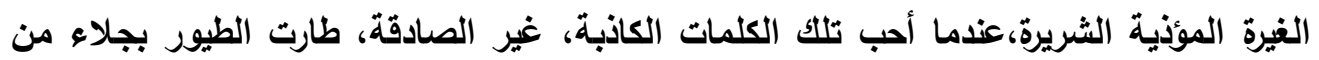

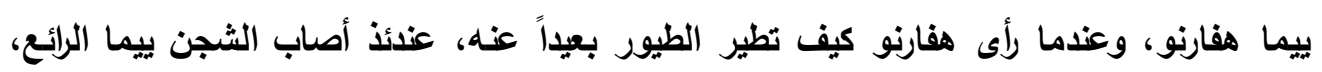

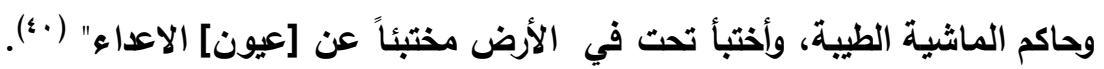

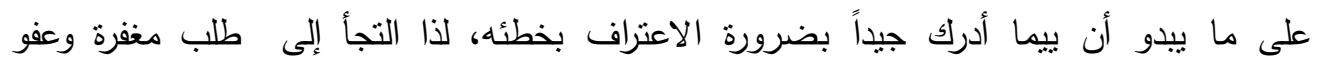
آهورامازدا الذي تاب عليه وغفر ذنوبه وتكرم عليه بشرف الحديث إليه، واعاد له المكانة الرفيعة

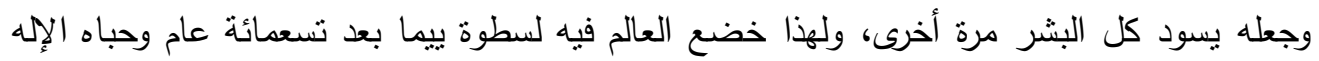

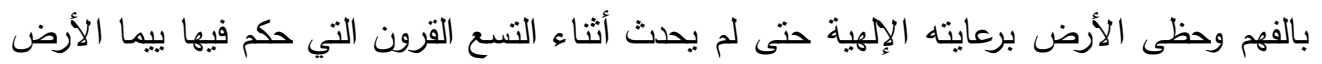

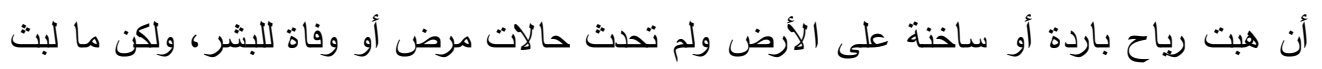

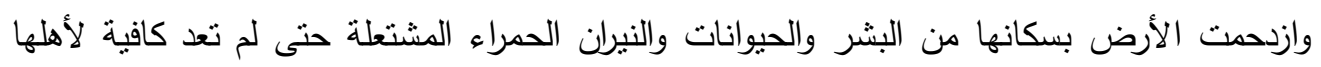

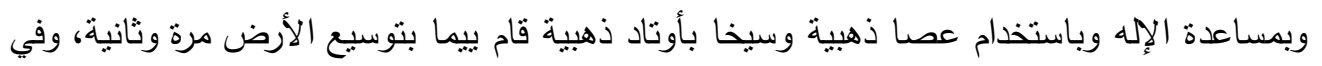

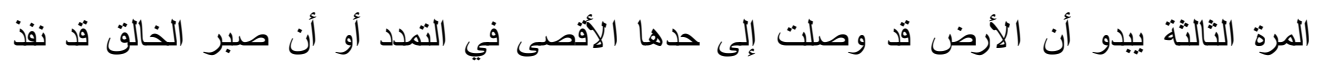
نتيجة لكثرة وتوسع من على الأرض وارتكابهم للخطايا والذنوب، مما أسهم ذلك في الأل في أن الآلهة

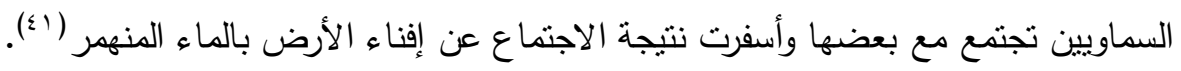
وقد قدمت فرضية جديدة لم تكن النصوص الزرادشتية قد أنشارت إليها من قبل في

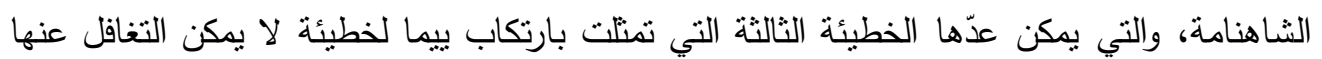

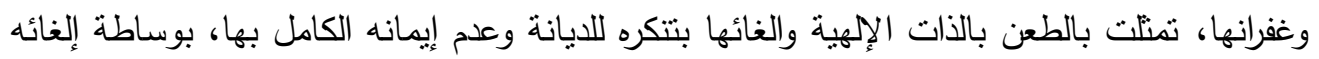

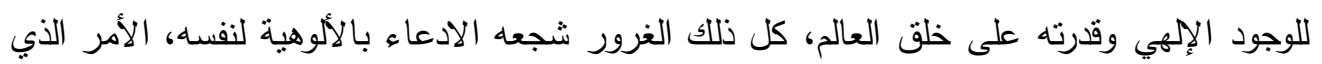

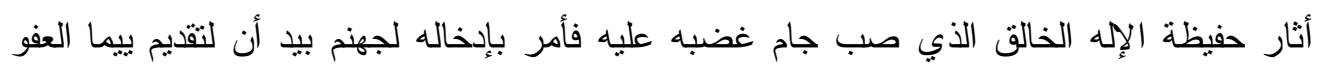

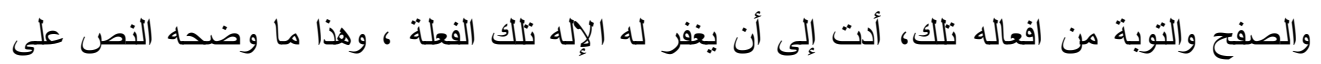


العـــــــــد السـابع والثلاثون

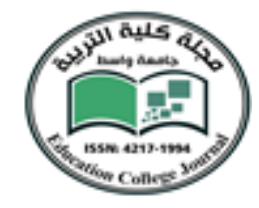

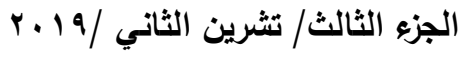

جامعة واسط

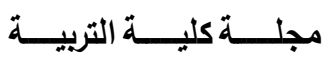

" غرَّ ييما بذاته، أعلن نفسه إلهاً وخالقاً للعالم، فَأُدين لأجل هذا والقي به في جهنم. يدرك ييما

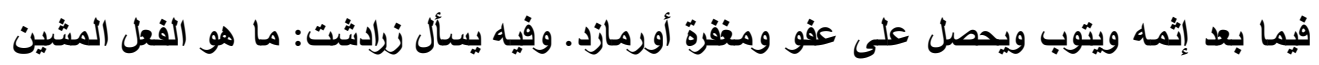

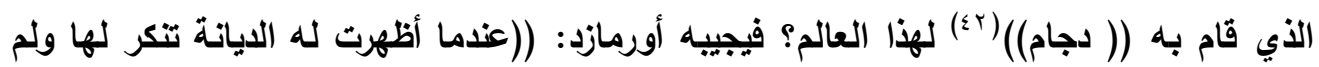

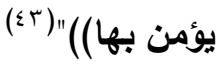

يتضح مما استعرض آنفاً، أن ييما أرتكب الشرور لدرجة جعلته بتطاول على الآلهة لابل

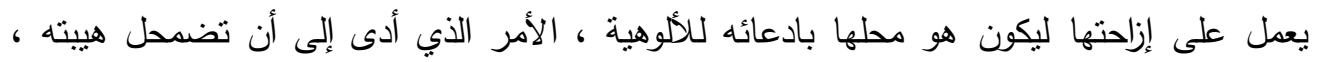

حتى أن شعاع السعادة الإلهي فارقه (؛ ؟).

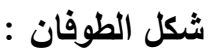

لقد أختلفت الدصادر في الشرق الأدنى القديم بشأن شكل الطوفان الذي ضرب مناطقها

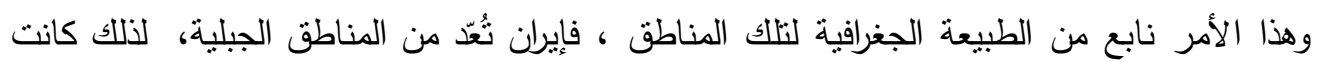

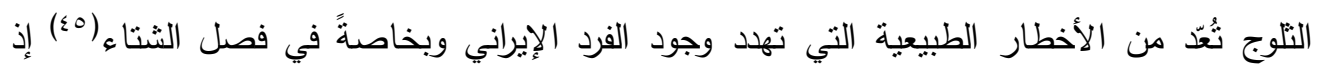

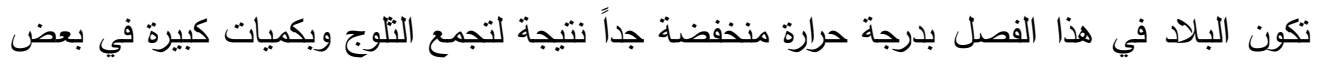

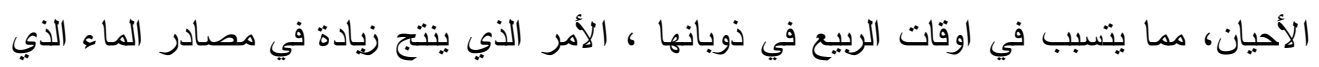

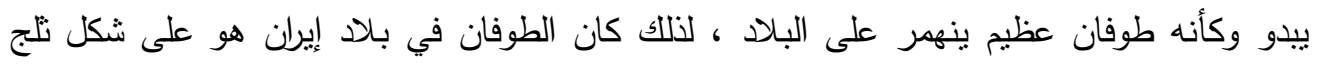

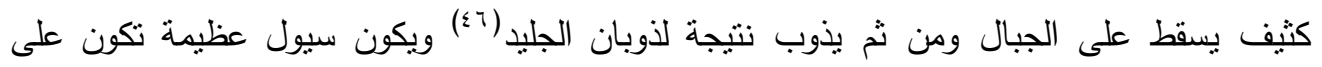

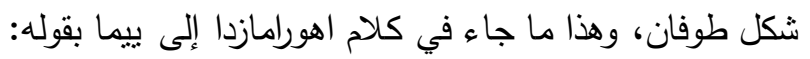

" قال اهورامازدا لـ ((باييما الرائع أبن فيفاهفانت ستحل شتاءات إلى هذا العالم المادي الاثم

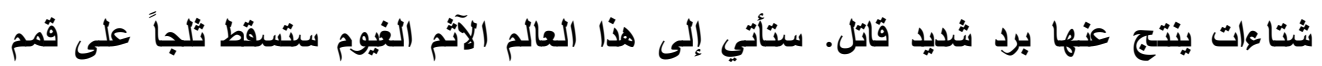
الجبال وعلى وديان نهر أردفي.) (

في ضوء ما تقدم، يبدو أن النظرة الإلهية البعيدة الددى قد أدركت شكل الصعاب والكارثة التي

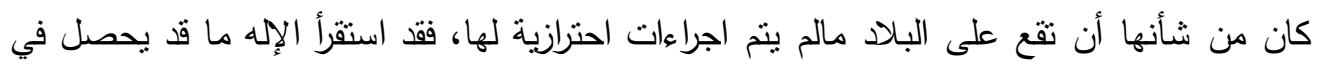

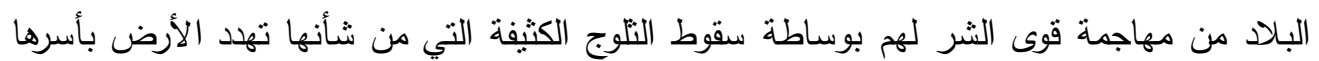
وإبادة من عليها من كائنات ومخلوقات كان قد صنعهات لهنها الإله آهورامازدا.

شدة الطوفان : السؤال الذي يطرح نفسه كيف كانت شدة نلك الطوفان ؟ هل هو من النوع البسيط أم

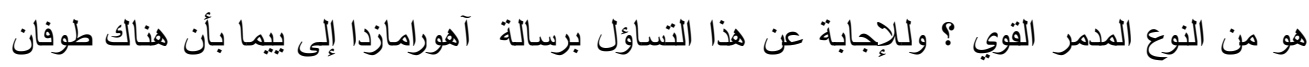


العـــــــــد السـابع والثلاثون

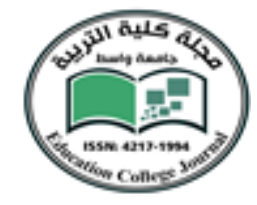

الجزء الثالث/ تشرين الثاني / 19

جامعة واسط

مجلـــــة كليـــــة التربيـــــة

كبير، وبلغ في شدته أنه أخذ بإبادة جميع المخلوقات لاسيما الحيوانية منه التي سوف ييقى جزء منها

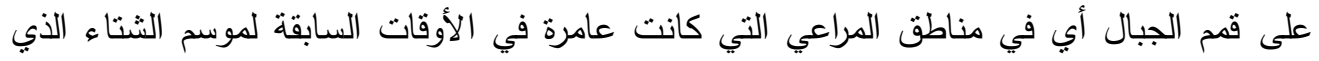

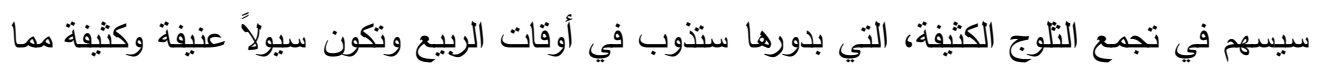

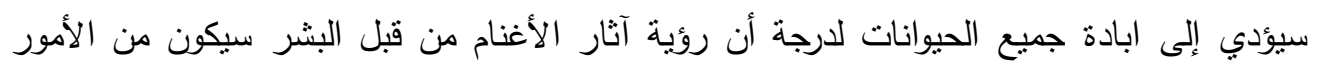

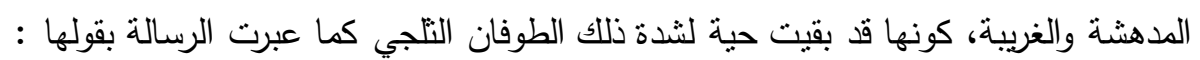
" سيبقى ثلث الماشية يا ييما على قيد الحياة في أماكن فظيعة التي تقع على قمم الجبال، أو في

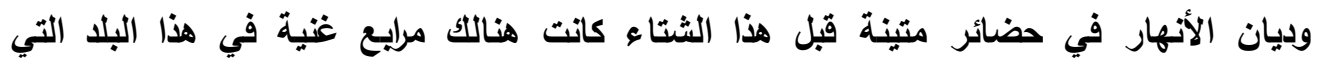

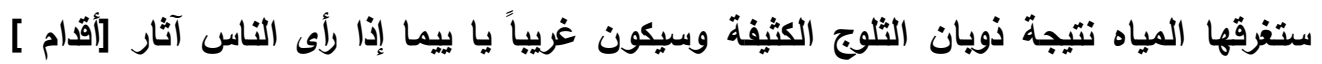

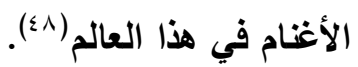

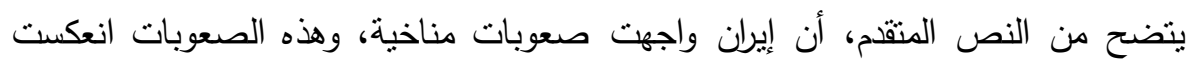

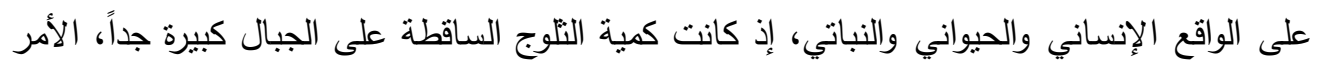
الذي أسهر بعد مجي فصل الصيف مع إخفاض درجة الحرارة إلى ذوبان النلوج التي شكلت تهديداً

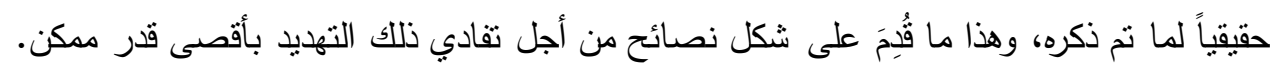

مدة الطوفان :

اكدت النصوص الأسطورية التي وردت في أفتتا عن قصة الطوفان في إيران القديمة، أنَّ الطوفان

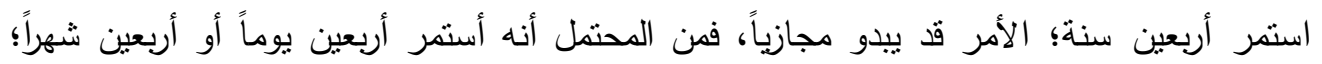

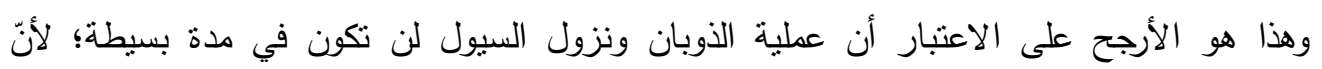

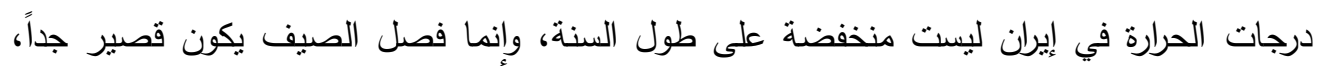

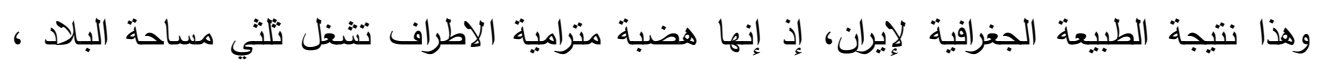
وتحيط تلك الهضبة سلاسل من الجبال الشاهقة من كل جوانبها، فضلاً عن وقوع الهضبة الإيرانية

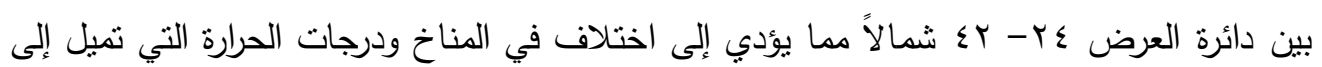

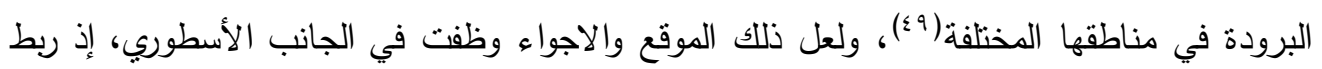

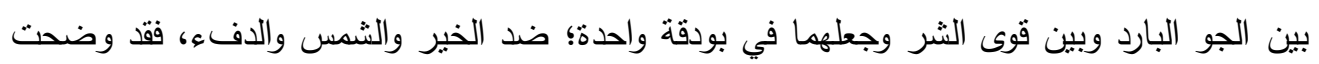

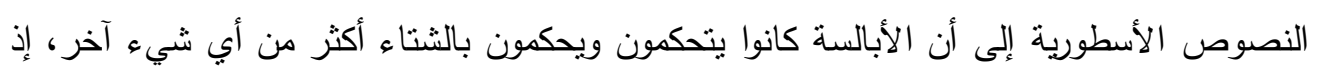

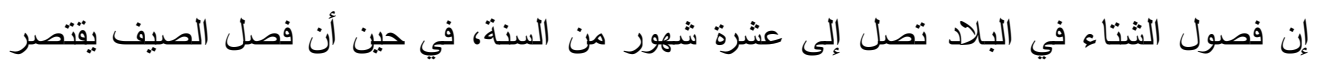


العــــــــد السابع والثثلاثون

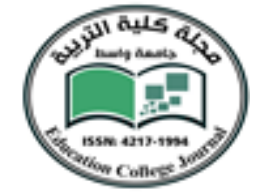

جامعة واسط

الجزء الثالث/ تشرين الثاني / 19

مجلـــــة كليـــــة التربيـــــة

على شهرين فقط، وحتى في هذين الثهرين تكون المياه والنباتات والأرض باردة، ولهذا يمتل الثتاء عدو لكل ما تم ذكره إلى جانب الإنسان، وبذلك يكون الجميع الذين يمتلون مخلوقات الإله آهورامازدا

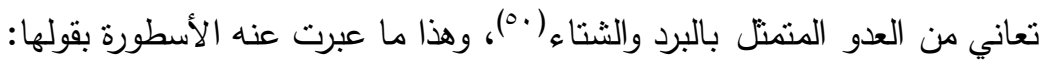

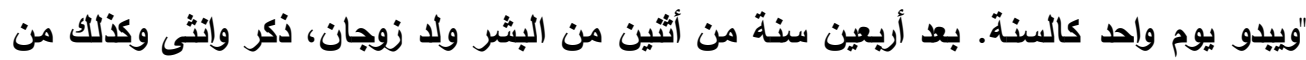

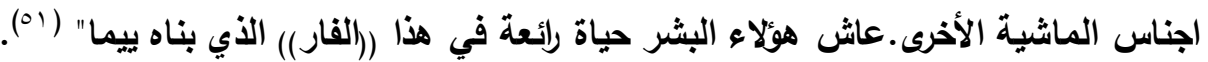

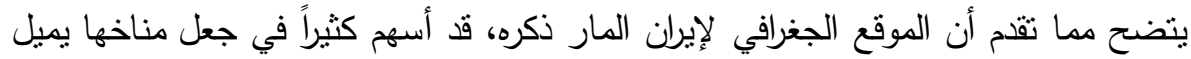
إلى البرودة، الأمر الذي حتم على الإنسان من مواجهة صعوبات، هددت وجودهم البشري والحيواني

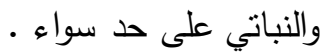
وصايا الإله آهورامازدا إلى ييما : وجه آهورامازدا النصائح والوصايا إلى ييما التي من شأنها أن تُشهم بإنقاذ الثلة القليلة من المخلوقات والنجاة من الموت المُحتم القادم نتيجة للطوفان النلجي الذي سيضرب المنطقة (في إيران)

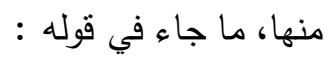
" وأنت ستبني ((فار)) بمساحة جري الخيل من الجهات الأريعة. أجلب فيه عائلة الأبقار، الأغنام،

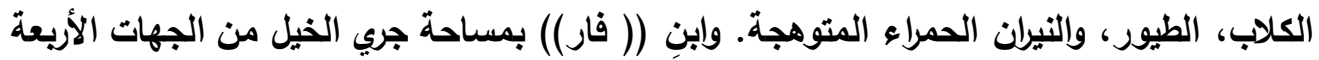

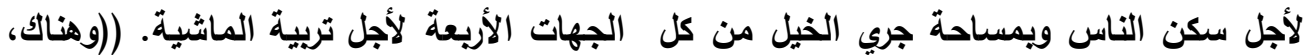

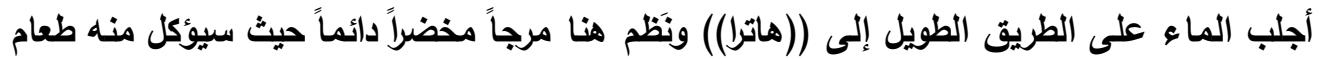

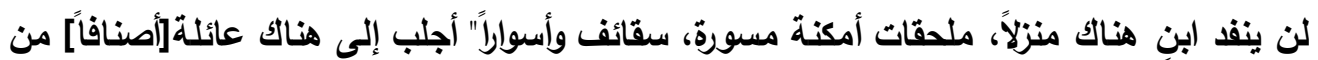
كل الكلاب وإلكلبات التي هي الأعظم الأفضل والأروع على هذه الارض. أجلب إلى هناك عائلة من

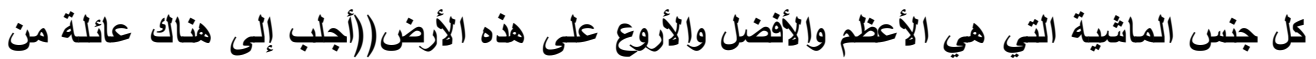

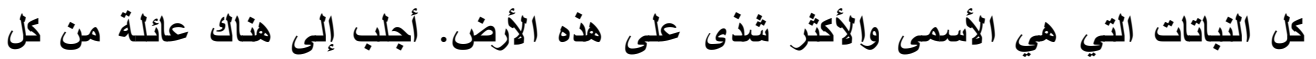
الأطعمة التي هي الألذ والأكثر شذى على هذه الأرض؟ وأجعل كل منها زوجاً [ ذكراً وانثى ] عندما

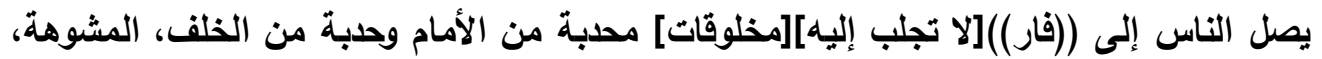
تلكك التي تحمل الثامات، المريضة، المنحرفة، ذات الأسنان المسوسة، الجرزماء، الأجساد

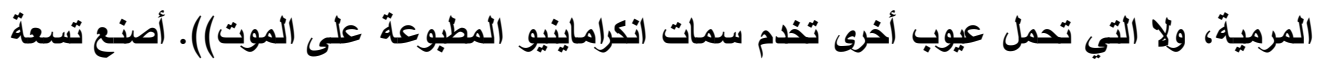

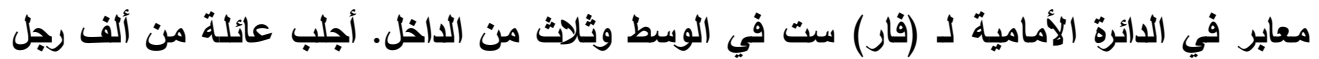


العـــــــــد السابع والثثلاثون

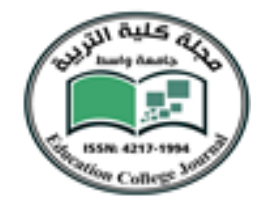

الجزء الثالث/ تثرين الثاني / 19

جامعة واسط

مجلـــــة كليـــــة التربيــــة

وامراة من معابر [الدائرة] الأمامية وستمئة من المعابر الوسطى ، وثلثمئة من المعابر الاخلية.

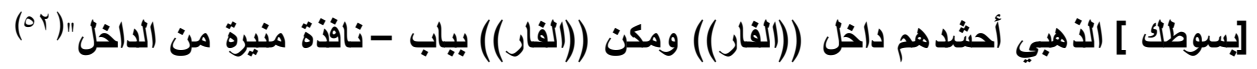

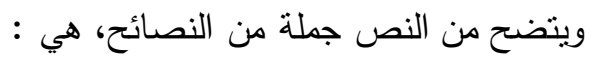

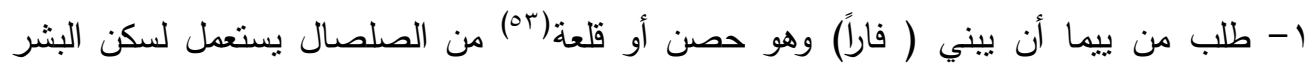

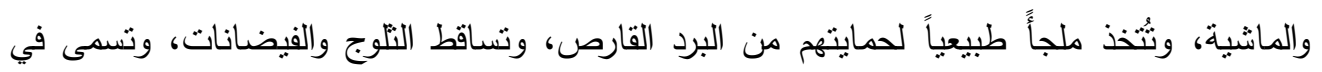

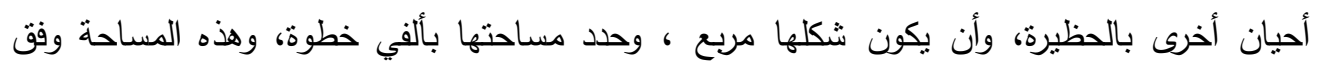

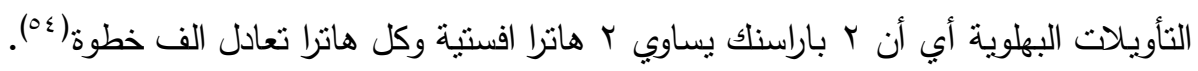
r- ونصحه بأن يجلب من كل صنف من الحيوانات زوجين (ذكر وأنثى)، من الأبقار والأغنام

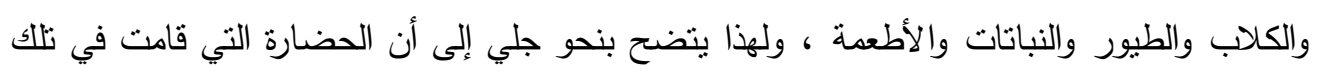

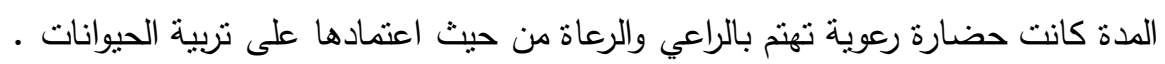

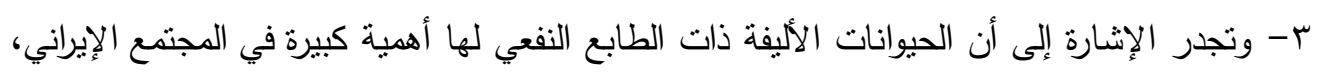

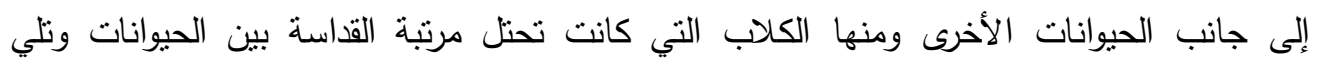

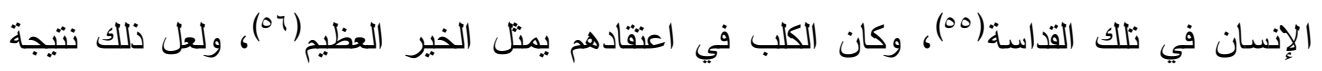
للطبيعة الجبلية للمنطقة واعنماد سكانها على هذه الحيوانات في حماية قطعان المانية وقيادتها

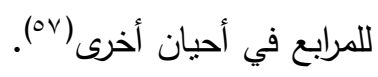
ع- ومن أجل أن نستمر الحياة ويستمر العنصر البشري كان لابد من الايعاز إلى ييما بجلب

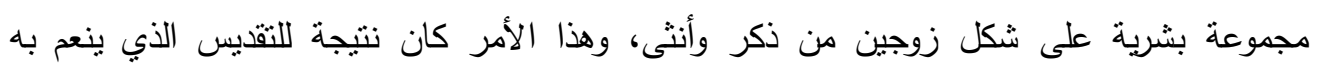

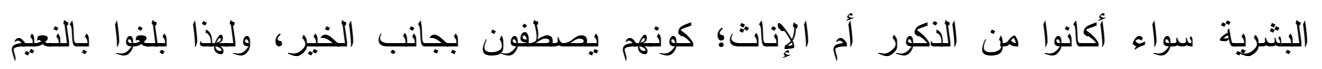

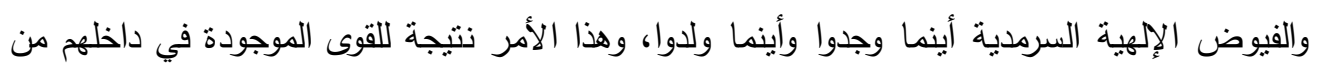

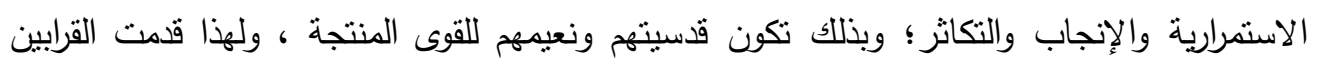

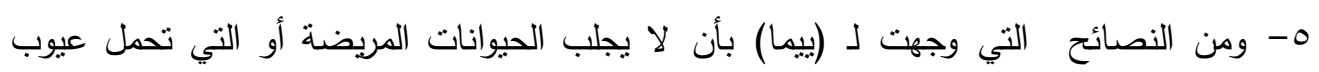
معينة لا بل الأمر تعدى ذلك فلم يكن يقتصر على الحيوانات حسب ، بل شمل الإنسان كنلك فأشار

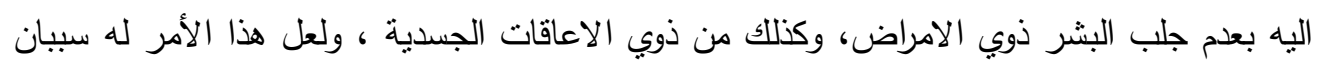

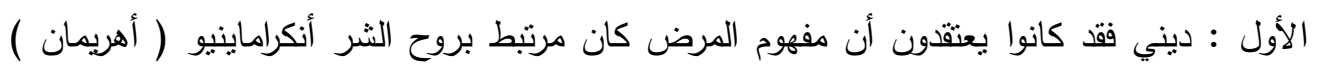

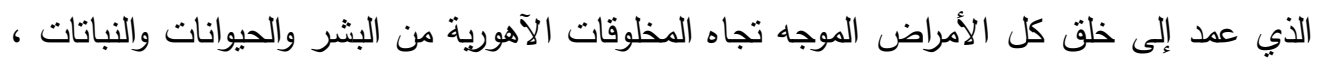


في حين أشار هيرودوت إلى أن الفرس كانوا بعتقدون بأن الامراض التي تصيب البشر إنما هي

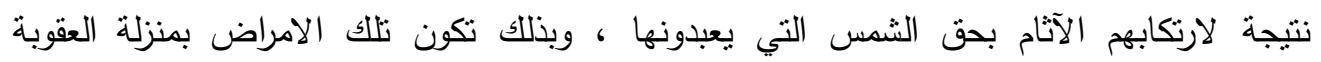

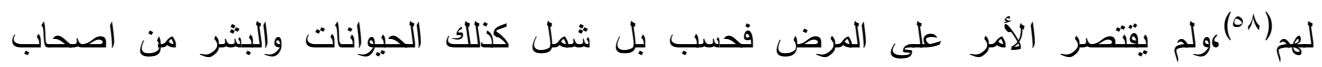

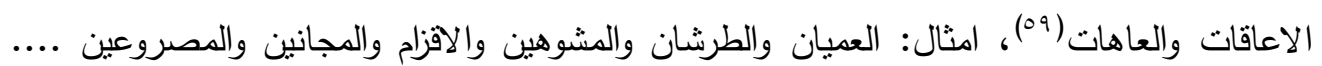

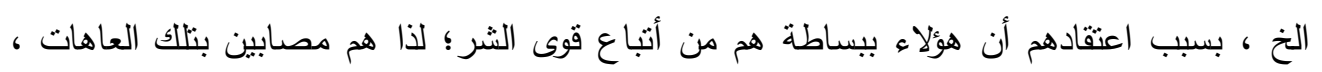

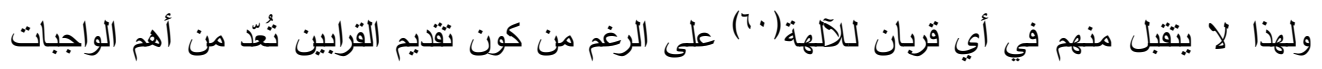

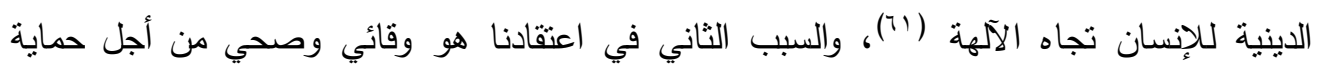

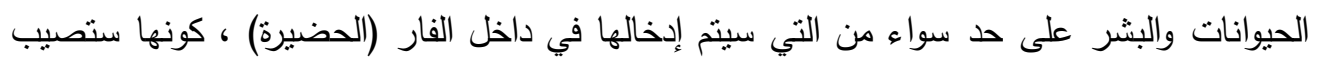

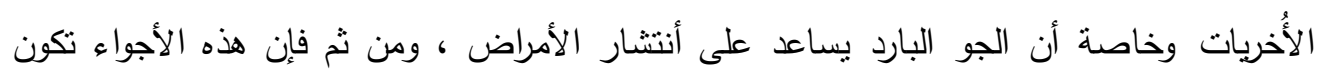

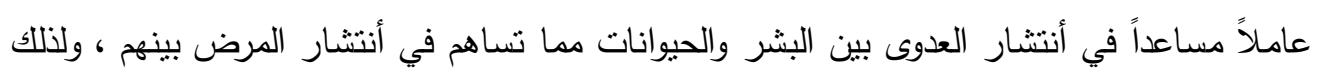

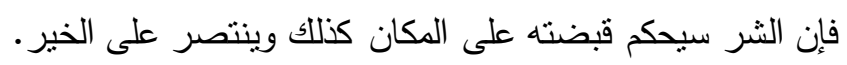

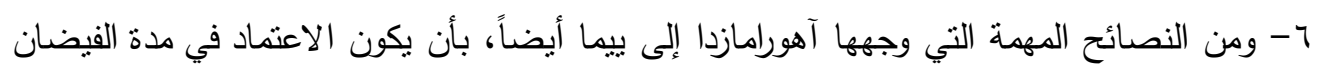

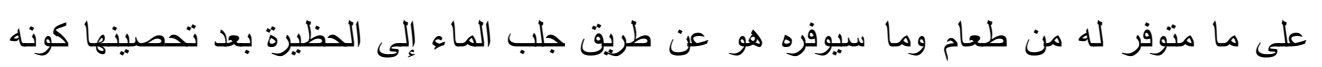

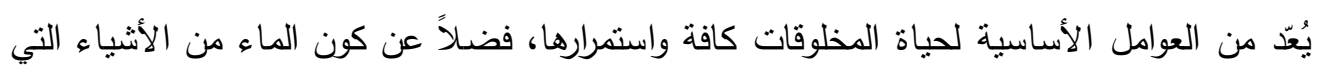

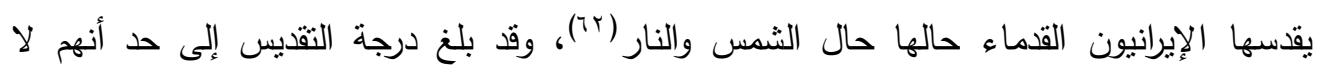

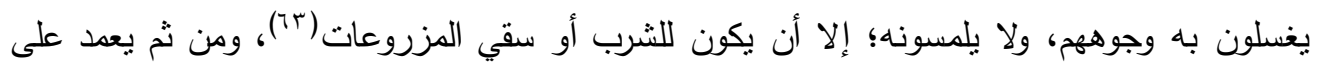
زراعتها بمختلف الأشجار سواء أكانت المثمرة منها أم تلك التي تكون ذات ألكات رائحة زكية ، لتقوم بإعالة

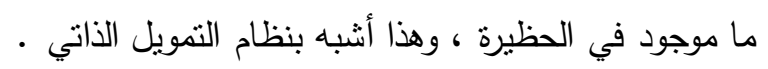

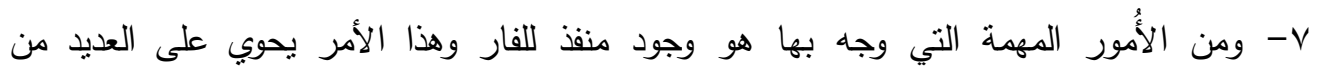

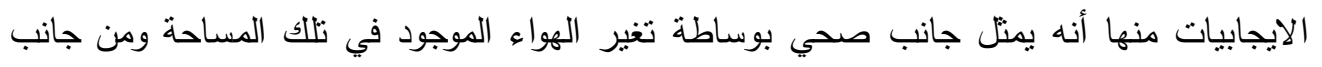

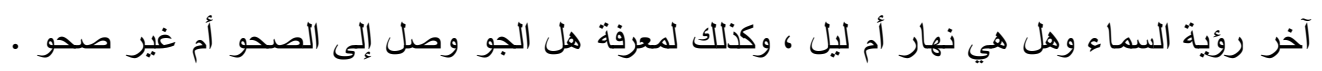

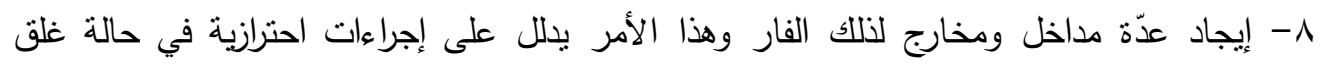

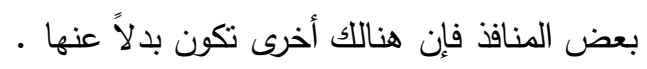

ومن مجريات الأحداث لهذه الأسطورة فإن ييما طلب من آهورامازدا بنطبيق ما تم الإشارة إليه، ولكن

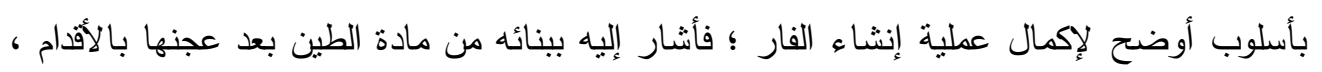

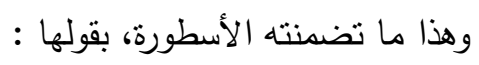


العــــــــد السابع والثثلاثون

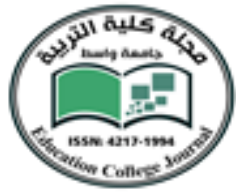

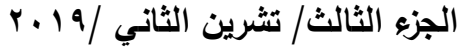

جامعة واسط

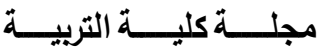

" هكذا فكر ييما: ((كيف سأبني (( فار)) الأي اخبرتني عنه آهورامازدا؟)) عندئذ قال آهورامازدا لـ ييما: ((باييما أبن فيفاهفاتت! اعجن الطين بأقدامك وتصور بيايك [ ومن ثم تعلم ] كيف يلصق

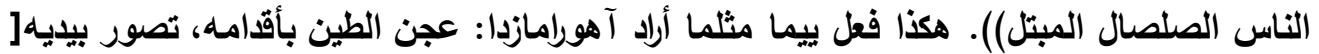

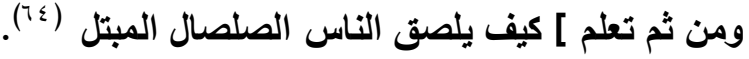

ونلحظ مما تقدم، أن عملية البناء تلكاء للفار تمت بوساطة مادة الطين التي تُعْدّ من بين أكثر المواد سهولة في الاستخدام وقلة في التكاليف، فضلاً عن كون لها القدرة بالربط بالمواد الأساسية

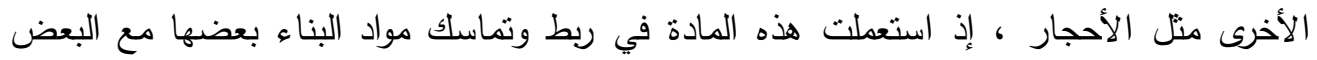

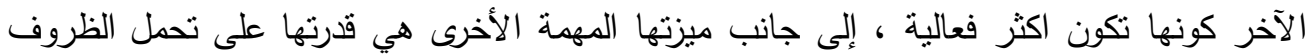

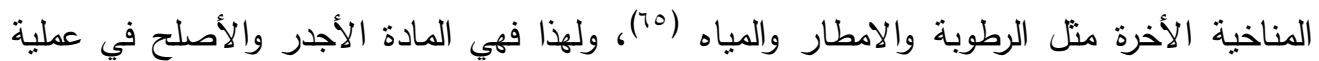

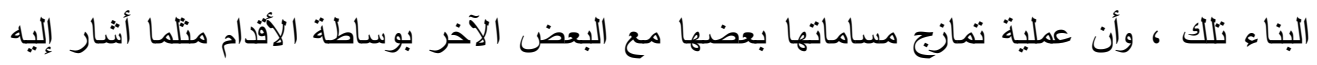
الإله بذلك، مما يزيد من كثافة تلك المادة .

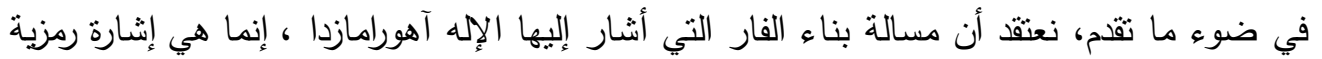

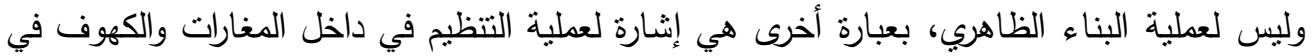
المذاطق الجبلية، إذ إن عملية بناء قلعة أو حصن نكون مكثوفة من جهة السماء منلما يوضح معنى

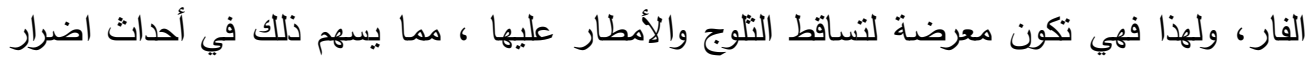

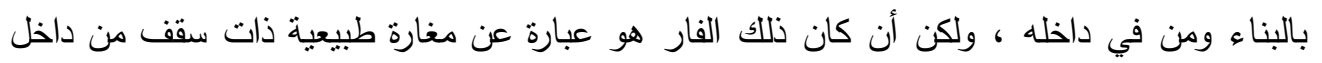
جبل أو هضبة ، كانت تحتاج فقط إلى عملية تنظيم لهذا المكان الذي يستخدمه الرعاة أثثاء عملية الرعي بعد مواجهنهم لظروف مناخية قاسية تحول دون وصولهم إلى ديارهم في بعض الاوقات .

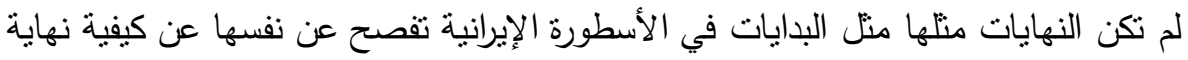

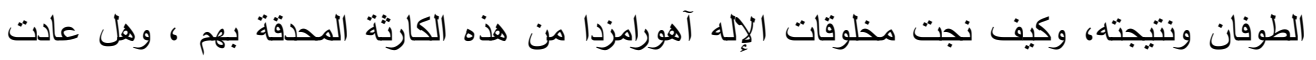

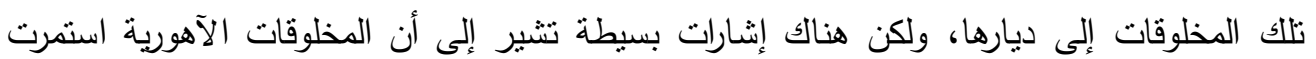

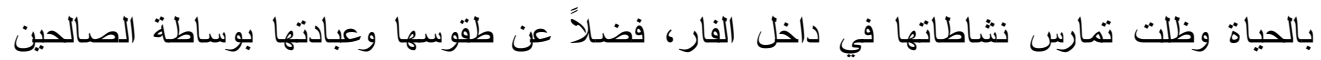

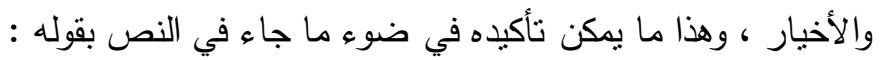
" يا خالق عالم الاجساد، يا قدوس! من اتى بدين هرمزد إلى الفار الذي عمله ييما؟ اجاب هرمزد: هو الطائر كرشيبيتر يا زرادشت القيس، يا خالق علم الاجساد يا قدوس، من هو الرئيس الزمني

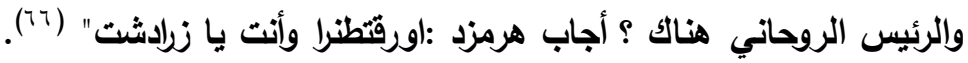


العـــــــــد السـابع والثلاثون

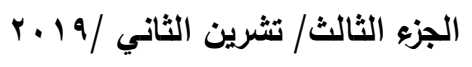

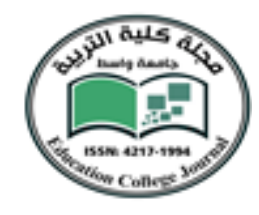

جامعة واسط

مجلــــة كليــــة التربيـــة

بلحظ مما تقدِم، أن تلك الكائنات الحية التي عاشت في داخل الفار استطاعت الصمود

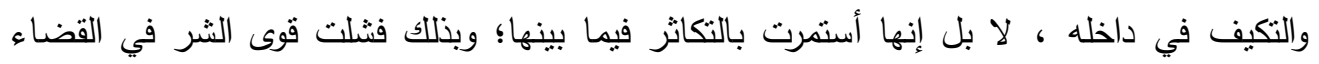
عليهم، وبذلك كانت الخاتمة نتلك الذصر للحق ومن يناصره، وهذا هو جزء من المعتقدات الإيرانية التي كانت سائدة .

الاستتتاجات :

من دراستتا لموضوع : (الطوفان في المصادر الإيرانية القديمة) بمكن أن نقف على أهم ما التي توصلت إليه هذه الدراسة ويمكن إجمالها بالنقاط الآتية:

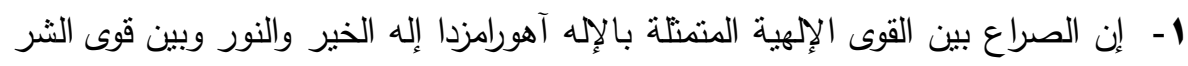

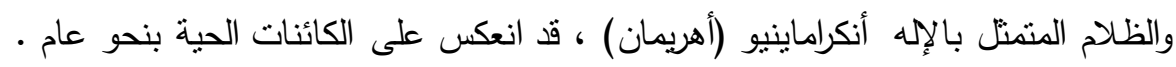

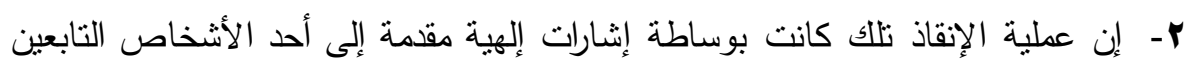

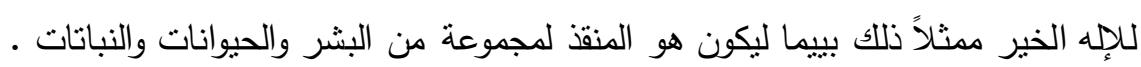

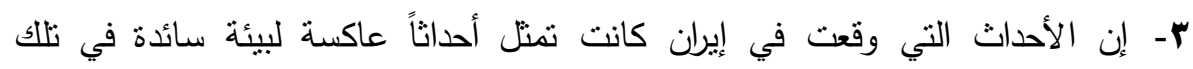

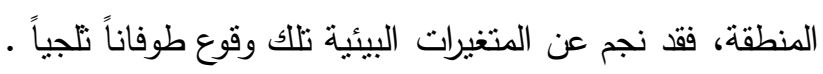
צ - كانت النهايات نشير إلى استمرار العنصر البشري والحيواني والنباني على الأرض،

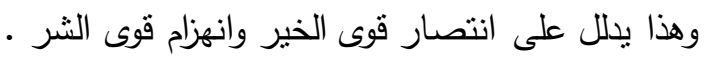

الهوامش والمصادر :

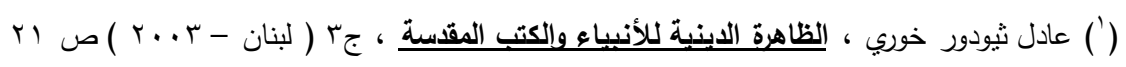

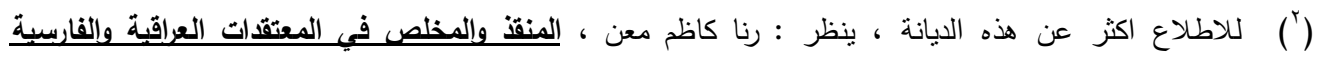

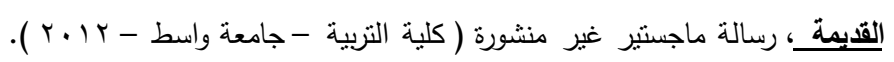

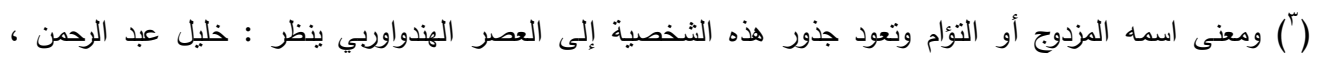

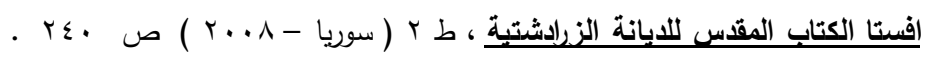

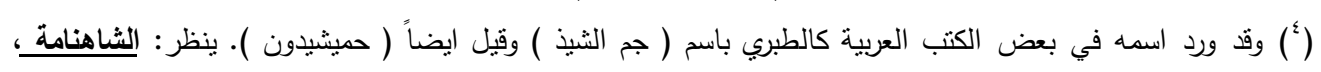

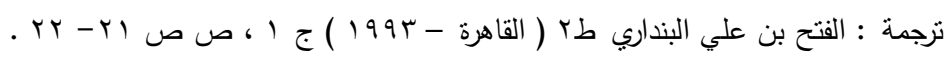

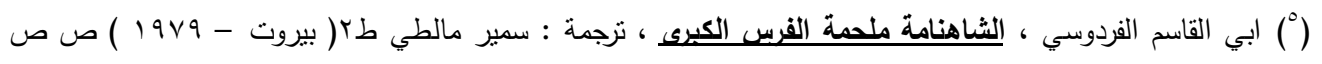
. 1. - 9 (") المصدر والصفحة نفسهما. 


\section{العــــــــد السـابع والثثلاثون}

الجزء الثالث/ تشرين الثاني / 19

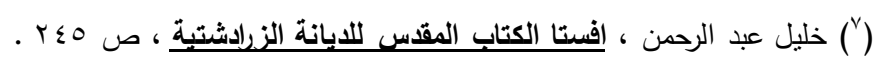

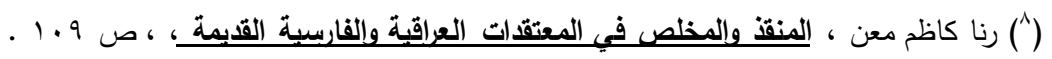

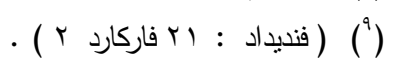

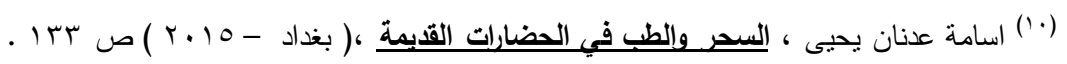

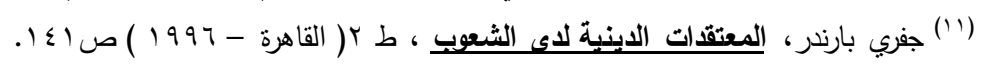

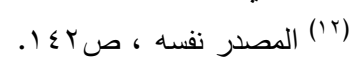

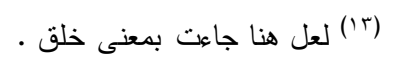

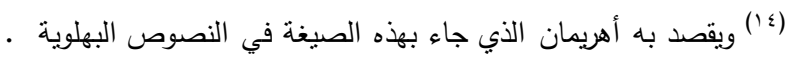

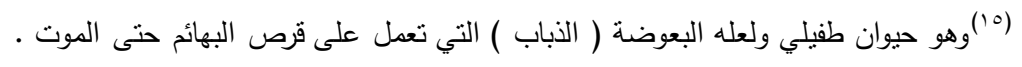

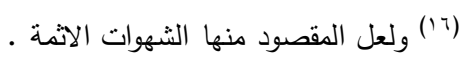

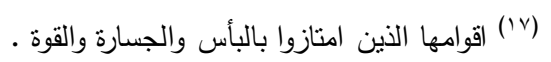

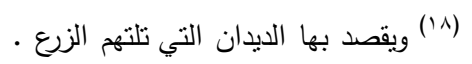

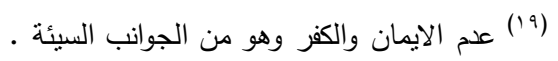

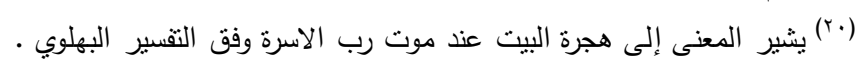

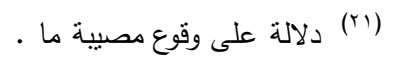

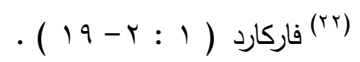

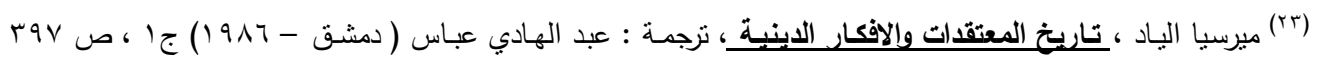

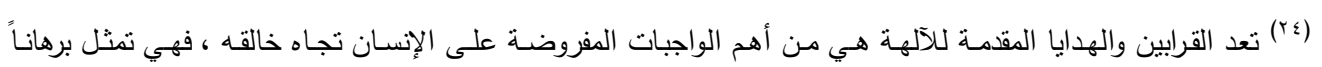

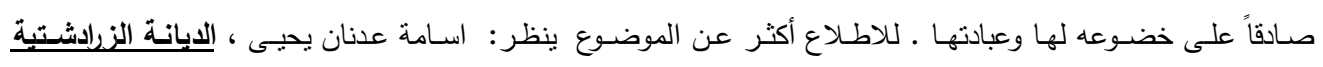

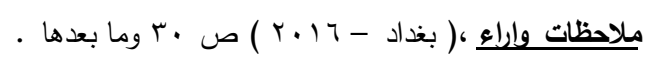

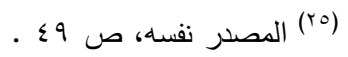

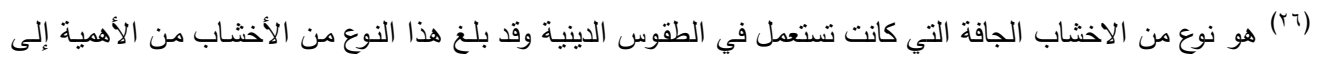

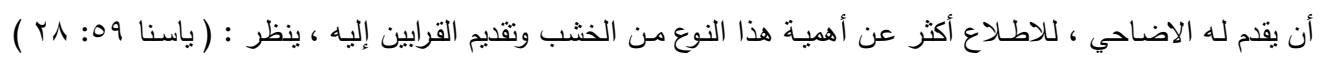

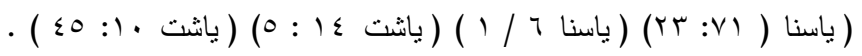

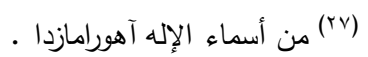

$$
\begin{aligned}
& \text { (r) }
\end{aligned}
$$

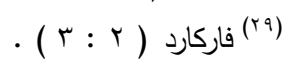

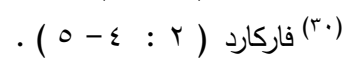

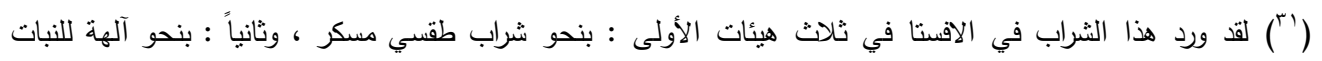

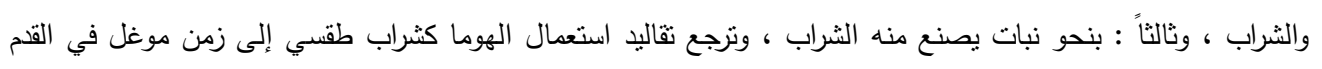




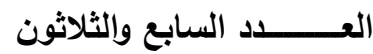

، إذ يعتقد أنه يصل إلى عصر جماعة الهندوأوربية أو يماذل هذا الثراب السوما الفيدي ، ووفقاً للافستا فإن هذا الشراب

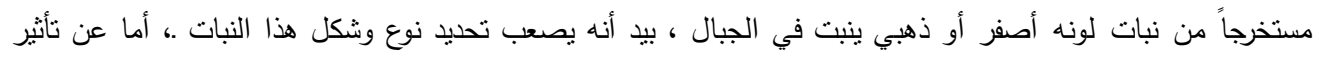

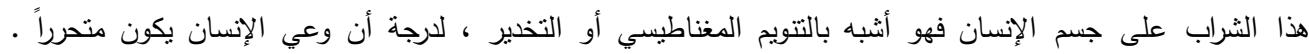

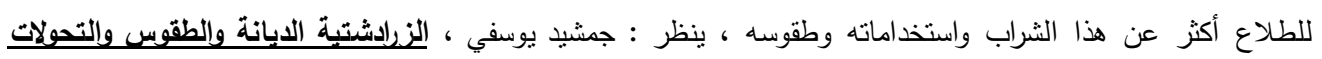

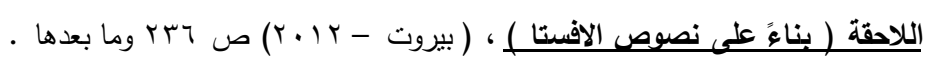

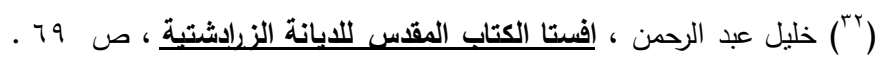
.

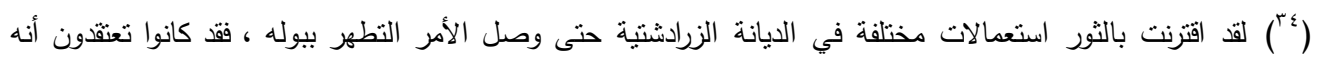

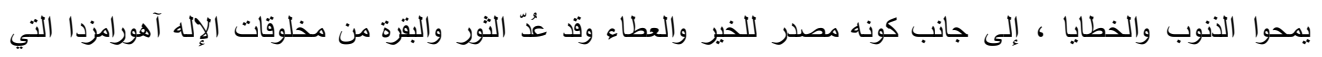

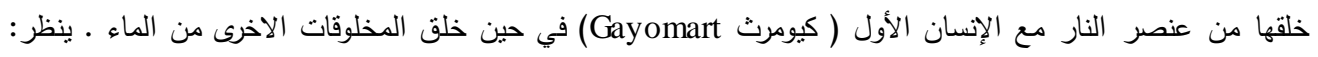

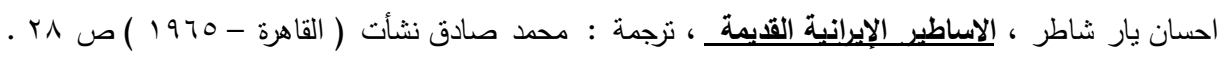

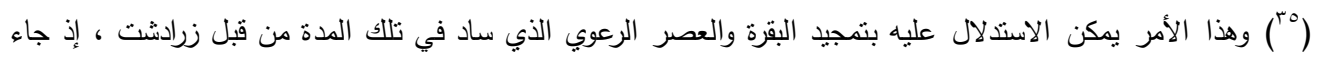

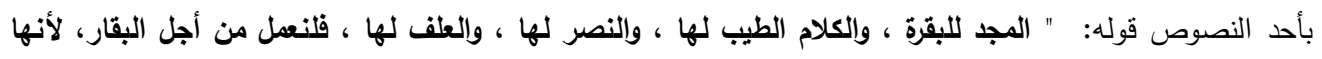

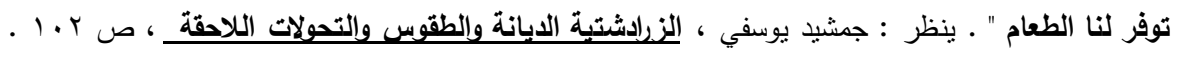

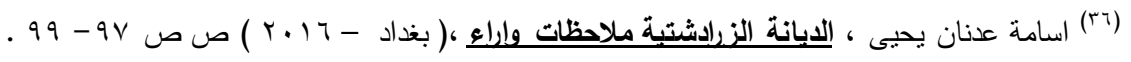

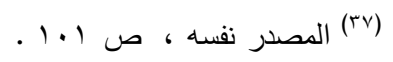

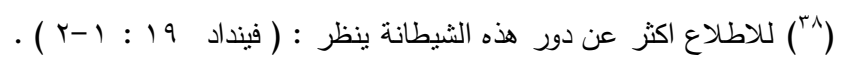

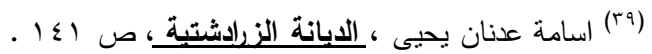

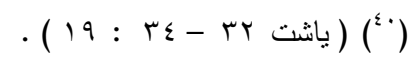

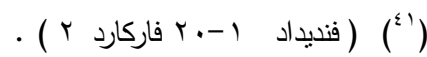

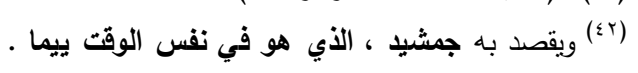

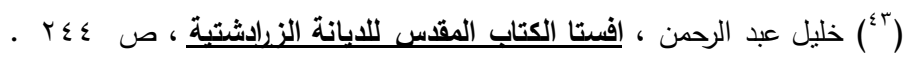

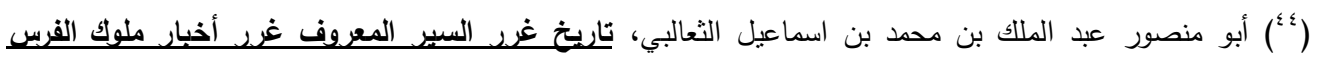

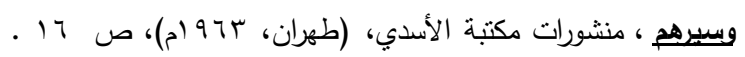

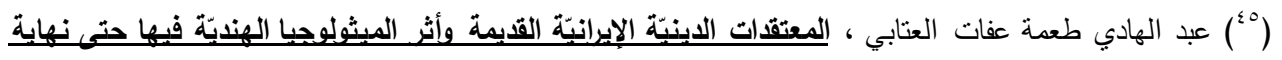

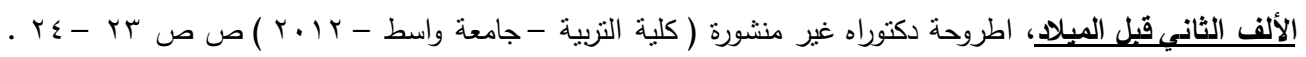

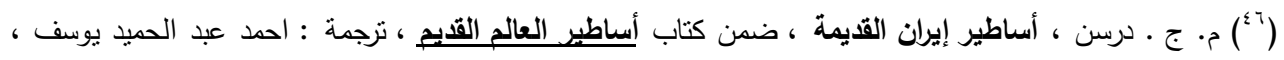

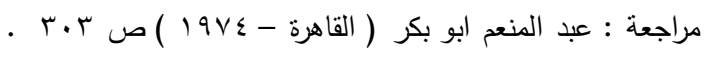

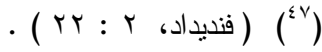

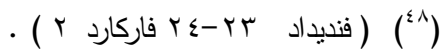




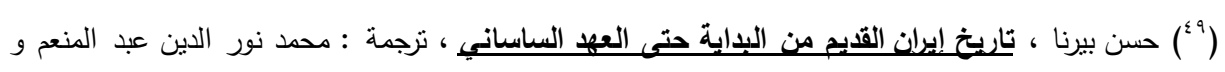

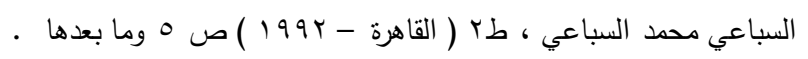

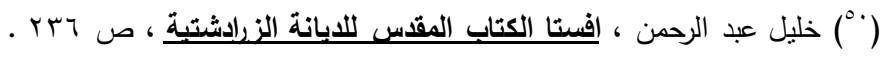

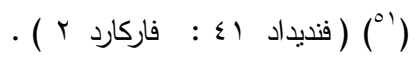

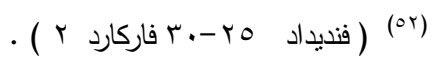

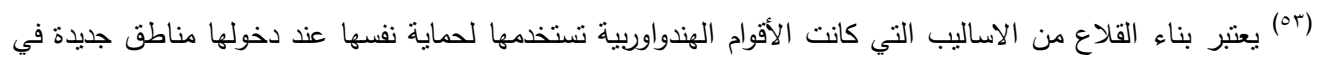

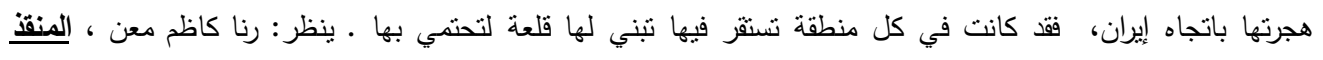

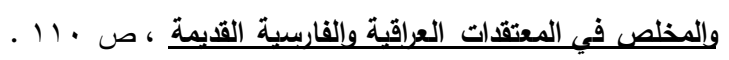

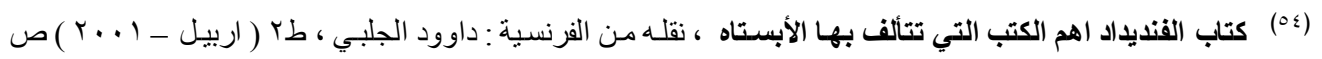

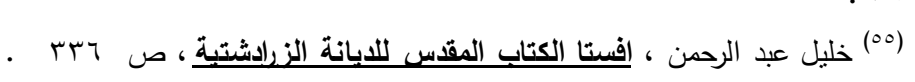

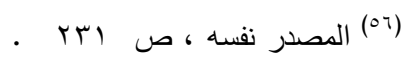

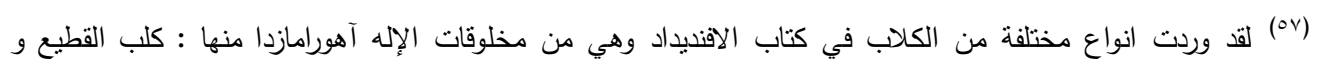

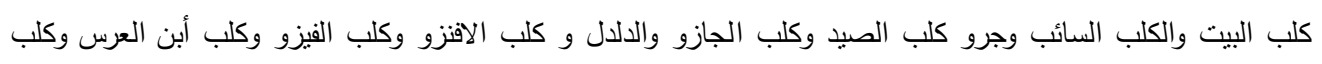

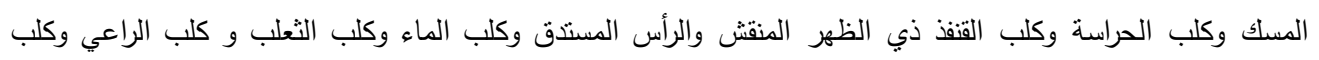

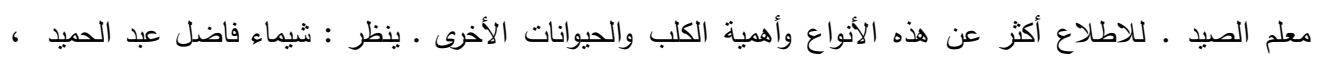

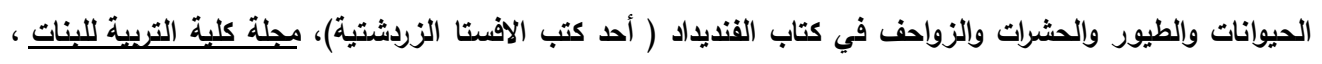

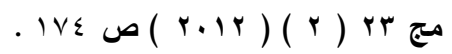

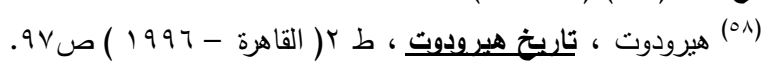

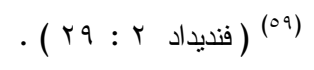

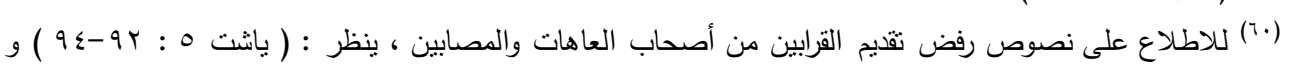

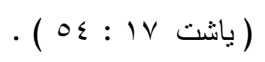

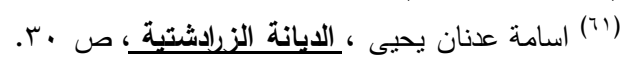

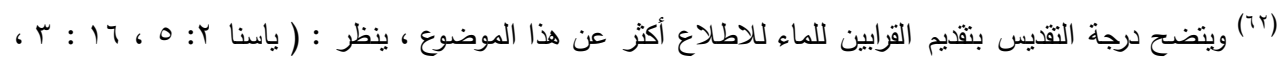

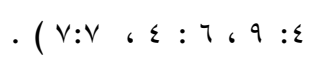

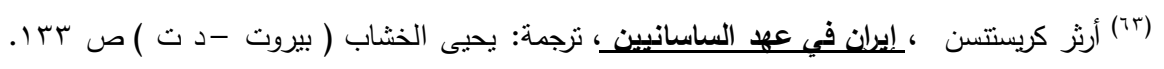

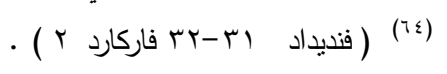

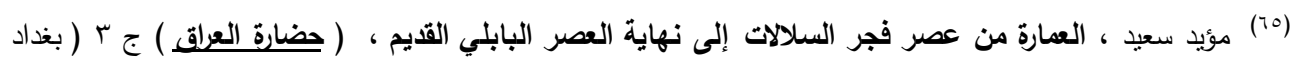

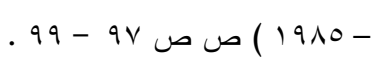

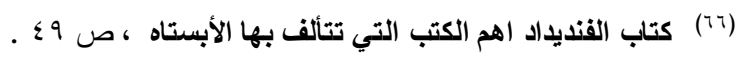

